\title{
A família Asteraceae em Um fragmento florestal, Viçosa, Minas Gerais, BrasiL ${ }^{1}$
}

\author{
Silvana da Costa Ferreira ${ }^{2}$, Rita Maria de Carvalho-Okano ${ }^{3}$ \\ \& Jimi Naoki Nakajima ${ }^{4}$
}

\begin{abstract}
Resumo
(A família Asteraceae em um fragmento florestal, Viçosa, Minas Gerais, Brasil) Este trabalho consiste no levantamento florístico e estudo taxonômico da família Asteraceae, da Estação de Pesquisa, Treinamento e Educação Ambiental, Viçosa, Minas Gerais. Foram amostradas 61 espécies circunscritas a 39 gêneros e 10 tribos. As tribos mais ricas em número de espécies foram Eupatorieae, com 22 espécies, Heliantheae com 11 spp., Astereae, com 10 spp. e Vernonieae com 8 spp. Os gêneros com maior abundância em número de espécies foram Mikania Willd. com oito spp., Baccharis L., com sete spp., Vernonia Schreb. com seis spp e Chromaloena DC. com três spp. Os demais gêneros apresentaram uma ou duas espécies. São fornecidas nesse trabalho chaves analíticas, descrições, ilustrações, comentários taxonômicos e distribuição geográfica para cada espécie.
\end{abstract}

Palavras-chave: Asteraceae, taxonomia, floresta Atlântica, Minas Gerais.

\section{Abstract}

(The family Asteraceae in the forest fragment, Viçosa, Minas Gerais, Brazil) This work consists of the floristic and taxonomic study of the family Asteraceae, of the Center of Research, Training and Environmental Education "Mata do Paraíso", Viçosa, Minas Gerais. In total, 61 species from 39 genus and 10 tribes were identificaed. The most tribes in number of species were Eupatorieae, with 22 species, Heliantheae with 11 spp., Astereae, with 10 spp. and Vernonieae with 8 spp. The genus with larger abundance in number of species were Mikania Willd. with eight spp., Baccharis L., with seven spp., Vernonia Schreb. with six spp and Chromaloena DC. with three spp. The other genus represented in the study area by one or two species. Keys for taxon identification are presend, as wel as descriptions, illustrations, comments about important features for the idenfitication and geographic distribution for each species.

Key words: Asteraceae, taxonomy, rain forest, Minas Gerais.

\section{INTRODUÇÃO}

Asteraceae compreende cerca 1.600 gêneros e 23.000 espécies, bem distribuídas em regiões tropicais, subtropicais e temperadas, representando $10 \%$ de toda a flora vascular mundial (Andenberg et al. 2007; Bremer 1994). No Brasil, a família é representada por aproximadamente 180 gêneros e 1.900 espécies, distribuídas em diferentes formações vegetacionais (Barroso et al. 1991; Nakajima \& Semir 2001).

A família está posicionada na Ordem Asterales, normalmente sozinha ou junto com outras pequenas famílias. Cronquist (1988) considerou Asteraceae como única família da Ordem Asterales, relacionado-a com as Ordens Gentianales, Rubiales, Dipsacales e Calycerales. Atualmente, estudos filogenéticos baseados em dados morfológicos e moleculares, como os de APG II (2003), corroboram o posicionamento de Asteraceae em Asterales juntamente com outras dez famílias.

Mesmo sendo um táxon com numerosas espécies, Asteraceae sempre foi considerada como um grupo natural bem sustentado por caracteres sinapomórficos, tais como: lactonas sesquiterpênicas, cálice altamente modificado em pápus, anteras conatas com deiscência

Artigo recebido em 03/2009. Aceito para publicação em 11/2009.

${ }^{1}$ Parte da dissertação de mestrado da primeira autora, desenvolvida na Universidade Federal de Viçosa.

${ }^{2}$ Universidade Estadual de Feira de Santana, Depto. Ciências Biológicas, Programa de Pós-Graduação em Botânica, 44.031-460, Feira de Santana, BA, Brasil. Autor para correspondência: silvanacferreira@yahoo.com.br

${ }^{3}$ Universidade Federal de Viçosa, Depto. Biologia Vegetal, 36570-000, Viçosa, MG, Brasil.

${ }^{4}$ Universidade Federal de Uberlândia, Depto. Biologia, 38400-902, Uberlândia, MG, Brasil.

Apoio: CAPES. 
introrsa formando um tubo ao redor do estilete; mecanismo secundário de apresentação de pólen com estilete modificado funcionando como uma escova; ovário ínfero, bicarpelar com apenas um óvulo de placentação basal e fruto com endosperma constituído de apenas uma camada inconspícua (APG II 2003).

Para o Brasil, os levantamentos florísticos da família Asteraceae estão geralmente restritos aos campos rupestres, exceto a importante obra de Baker para Flora brasiliensis (1873, 1876, 1882, 1884). Em florestas têm-se apenas os estudos de: Leitão-Filho (1991) e Souza (2007), realizado na Ilha do Cardoso, São Paulo; Esteves \& Barroso (1996), na Reserva de Macaé de Cima, Rio de Janeiro; Nakajima et al. (2001), na Reserva do Parque Estadual das Fontes do Ipiranga e Moraes \& Monteiro (2006) para planície litorânea de Picinguaba. Em Minas Gerais, foram realizados os trabalhos de: LeitãoFilho \& Semir (1987) e de Roque \& Pirani (1997) na Serra do Cipó; de Hind (2003) em Grão Mogol; Nakajima \& Semir (2001) na Serra da Canastra e Hattori \& Nakajima (2008); todos, exceto o útimo, restritos às áreas de campos rupestres.

Diante da riqueza de espécies desta família e a carência de informações relativa aos fragmentos de mata estacionais semidecíduais, o presente trabalho teve por objetivo contribuir para o conhecimento de Asteraceae através do levantamento das espécies na Estação de Pesquisa, Treinamento e Educação Ambiental Mata do Paraíso, um fragmento de Mata Estacional Semidecidual, localizado em Viçosa, estado de Minas Gerais. São fornecidas chaves de identificação, descrições dos táxons, ilustrações das espécies, comentários taxonômicos, período de floração e frutificação, bem como verificada a abrangência da distribuição geográfica das espécies.

\section{Material e Métodos}

\section{Área de estudo}

A Estação de Pesquisa, Treinamento e Educação Ambiental Mata do Paraíso (Fig. 1), aqui denominada como (MP), abrange uma área de aproximadamente 194,36 ha, sob as coordenadas $20^{\circ} 45^{\prime} \mathrm{S}$ e $42^{\circ} 55^{\prime} \mathrm{W}$, e altitude média de 690 m (Leal-Filho 1992). Sua vegetação é classificada, segundo Veloso \& Góes-Filho (1982), como floresta estacional semidecidual, submontana ou montana e encontra-se em estádio avançado de sucessão secundária.

\section{Procedimentos de campo e de laboratório}

As coletas dos exemplares botânicos foram realizadas quinzenalmente no período de setembro de 2004 a setembro de 2005, ao longo da trilha principal, trilha circuito das águas, dos gigantes, do aceiro, no entorno das lagoas principal e menor, além de caminhadas aleatórias no interior da mata e em áreas abertas ao longo da trilha principal e do aceiro. O material coletado foi depositado no Herbário VIC.

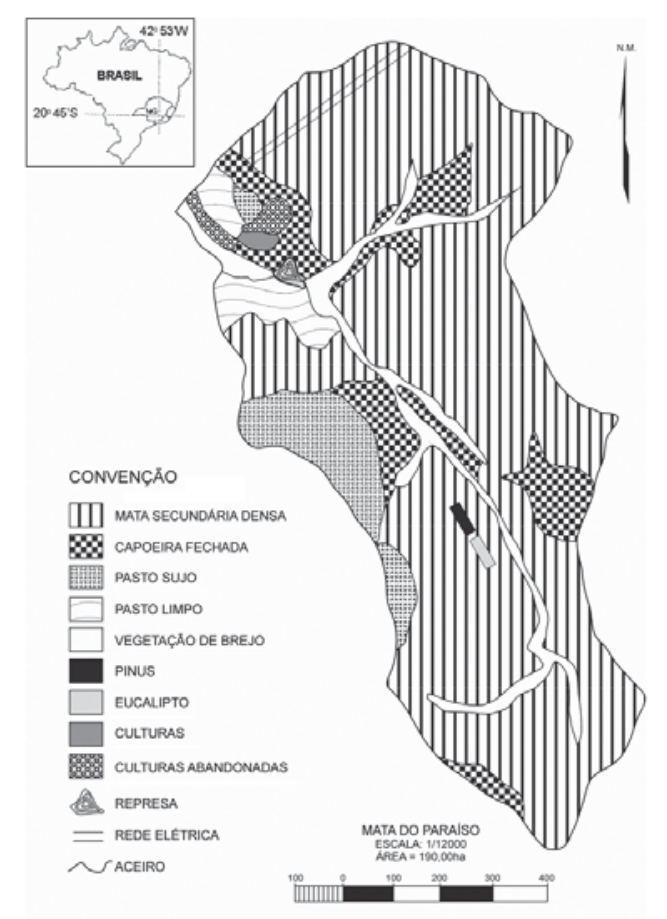

Figura 1 - Mapa com a localização e os ambientes encontrados na Estação de Pesquisa e Educação Ambiental Mata do Paraíso, Minas Gerais, Brasil.

Figure 1 - Map with the location and the ambients found in the Estação de Pesquisa e Educação Ambiental Mata do Paraíso, Minas Gerais, Brazil. 
Os espécimes botânicos utilizados para a realização das descrições são referentes às coletas realizadas exclusivamente para a família, de setembro de 2004 a setembro de 2005, além de outros exemplares depositados no Herbário VIC, provenientes de coletas anteriores ao início deste trabalho.

Para a identificação dos materiais utilizouse microscópio estereoscópico, bibliografia especializada, consulta a especialistas e comparações com materiais de outras localidades depositados nos Herbários VIC, RB, SP e SPF (siglas de acordo com Holmgren et al. 1990).

Como a família Asteraceae apresenta uma ampla variação morfológica, as descrições das espécies foram padronizadas dentro de cada gênero. As chaves e descrições para espécies foram baseadas nas variações morfológicas encontradas nos indivíduos ocorrentes na MP. A taxonomia dos gêneros pertencentes à tribo Eupatorieae seguiu o sistema de classificação proposto por King \& Robinson (1987) e os gêneros circunscritos à tribo Vernonieae, o sistema de Baker (1873).

\section{Resultados e Discussão}

Para a MP foram registradas 61 espécies circunscritas em 39 gêneros e 10 tribos. As tribos mais ricas em número de espécies foram Eupatorieae, com 22 spp., Heliantheae, com 11 spp., Astereae, com 10 spp. e Vernonieae, com 8 spp. Os gêneros com maior abundância em número de espécies foram Mikania Willd., com oito spp., Baccharis L., com sete spp., Vernonia, Schreb. com seis spp. e Chromaloena, DC. com três spp. Os demais gêneros apresentaram uma ou duas espécies.

\section{Chave para identificação dos gêneros de Asteraceae da MP}

1. Plantas latescentes, capítulos com todas as flores liguladas.

2. Receptáculo paleáceo; papilho plumoso 24. Hypochoeris

2'. Receptáculo epaleáceo; papilho cerdoso 33. Sonchus

1'. Plantas não latescentes, capítulos nunca com todas as flores liguladas

3. Capítulos homógamos.

4. Plantas dióicas

7. Baccharis

4'. Plantas monóicas.

5. Trepadeiras, capítulos com quatro brácteas involucrais e flores

26. Mikania

5'. Ervas, subarbustos, arbustos ou ávores, eretos ou prostados, capítulo com cinco ou mais brácteas involucrais e flores.

6. Folhas alternas ou basais rosuladas.

7. Brácteas involucrais unisseriadas, completamete conadas formando um invólucro gamófilo .... 17. Emilia

7'. Brácteas involucrais em duas ou mais séries, livres ou conadas apenas na base.

8. Flores com corola bilabiada; ramos do estilete com ápice truncado, penicilado. 38. Trixis

8'. Flores com corola tubulosa; ramos do estilete com ápice agudo, não penicilado.

9. Capítulos agregados em capítulos secundários, envolvidos por brácteas foliáceas; papilho 1-seriado ..... 16. Elephanthopus

9'. Capítulos simples, papilho 2-seriado.

10. Plantas com indumento lepidoto ou estrelado-tomentoso, brácteas involucrais internas caducas, antera com base longamente caudada 29. Piptocarpha 
10'. Plantas com indumento não lepidoto ou estrelado-tomentoso, brácteas involucrais internas geralmente persistentes, antera com base auriculada ou curto sagitada

39. Vernonia

6'. Folhas opostas.

11. Margem foliar com glândulas translúcidas; invólucro unisseriado .... 30. Porophyllum

11'. Margem foliar desprovidas de glândulas translúcidas; invólucro com duas ou mais séries de brácteas.

12. Papilho formado por escamas aristadas ou protuberâncias claviformes glandulosas.

13. Papilho formado por três protuberâncias claviformes glandulares

13'. Papilho formado por escamas aristadas.

14. Cipsela com bordas longamente ciliadas

14'. Cipsela sem bordas ciliadas

3. Adenostemma

2'. Papilho cerdoso (cerdas capilares).

15. Apêndice do conectivo da antera inconspícuo; ápice dos ramos do estilete

12'. Papilho cerdoso (cerdas capil
15. Apêndice do conectivo da
capitados e enegrescidos
15'. Apêndice do conectivo

35. Spilanthes

4. Ageratum 28. Ophryosporus

15'. Apêndice do conectivo da antera conspícuo; ápice dos ramos do estilete lineares ou clavados, nunca enesgrescidos.

16. Capítulo com até 10 flores.

17. Plantas escandentes ou apoiantes; corola interna e externamente pilosa

36. Steyermarkina

17'. Plantas eretas, corola glabra interna e externamente.

18. Capítulo com 9-10 flores, lobos da corola e cipselas com pontuações glandulares

6. Austroeupatorium

18'. Capítulo com 5 flores, lobos da corola e cipselas sem pontuações glandulares.

19. Lâmina foliar membranácea, pontuada de glândulas em ambas as faces, margem inteira

5. Austrocritonia

19'. Lâmina foliar cartácea, ambas as faces sem pontuações glandulares, margem serreada

23. Graziela

16'. Capítulo com mais de 10 flores.

20. Invólucro cilíndrico, 5-8-seriado

11. Chromaloena

20’. Invólucro campanulado; 3 -seriado.

21. Plantas arbustivas, base do estilete dilatada, ramos do estilete com ápice linear, cipsela pontuada de glândulas

25. Heterocondylus

21'. Plantas herbáceas, base do estilete não dilatada, ramos do estilete com ápice levemente clavado, cipsela sem pontuações glandulares.

22. Lâmina foliar com base cuneada, capítulos 40-45 flores, brácteas involucrais oblongas, cipselas comprimidas, 3-4 costadas 31. Praxelis

22'. Lâmina foliar com base obtusa, capítulos 20-25 flores, brácteas involucrais lanceoladas, cipselas não comprimidas, 5 costadas 20. Fleischmannia

3'. Capítulos heterógamos.

23. Trepadeiras; folhas com gavinha terminal

27. Mutisia 
23'. Ervas ou subarbustos, eretos ou prostrados, folhas sem gavinha terminal

24. Capítulos com flores trimorfas

10. Chaptalia

24' Capítulos com flores dimorfas.

25. Capítulos disciformes.

26. Invólucro unisseriado, caliculado

18. Erechtites

26'. Invólucro disposto em mais de uma série, não caliculado.

27. Face abaxial das lâminas foliares pubescente, margem das brácteas involucrais não hialinas, ramos do estilete oblongo-lineares, anteras acaudadas 13. Conyza

27'. Face abaxial das lâminas foliares albo-tomentosas, margem das brácteas involucrais hialinas, ramos do estilete truncados, anteras caudadas.

28. Capítulos com cinco flores, cerdas do papilho livres na base

2. Achyrocline

28'. Capítulos com mais de cinco flores, cerdas do papilho concrescidas na base

22. Gamochaeta

25'. Capítulo radiado.

29. Receptáculo paleáceo.

30. Papilho aristado, coroniforme ou paleáceo.

31. Papilho paleáceo ou coronifome.

32. Papilho paleáceo

21. Galinsoga

32'. Papilho coroniforme

34. Sphagneticola

31'. Papilho aristado.

33. Aristas do papilho com tricomas retrorsos.

34. Cipsela rostrada

14. Cosmus

34'. Cipsela não rostrada

8. Bidens

33'. Aristas do papilho sem tricomas retrorsos

9. Blainvillea

30'. Papilho ausente.

35. Cipsela das flores do raio cobertas por tricomas uncinados

1. Acanthospermum

35'. Cipsela das flores do raio glabras.

36. Brácteas involucrais externas espatuladas cobertas por tricomas glandulares

32. Sigesbeckia

36'. Brácteas involucrais externas sem as características acima.

37. Páleas lineares, superfície da cipsela verrucosa .... 15. Eclipta

37'. Páleas não lineares, cipsela com superfície não verrucosa ..

37. Tilesia

29’. Receptáculo epaleáceo.

38. Papilho cerdoso

19. Erigeron

38'. Papilho ausente

12. Chrysanthemum

1. Acanthospermum australe (Loefl.) Kuntze, Revis. Gen. Pl. 1: 303. $1891 . \quad$ Fig. 2a

Melampodium australe Loefl., Iter Hispan. 268-269. 1758.

Ervas ca. $15 \mathrm{~cm}$, eretas; caule tetragonal, estriado, tomentoso. Folhas opostas, membranáceas, ovadas, $2-3 \times 1,8-3 \mathrm{~cm}$, ambas as faces pubescentes, pontuadas de glândulas, ápice obtuso, margem crenado-serreada, base atenuada, pecíolo 3-5 mm compr. Capítulos homógamos, discóides, pedunculados, pedúnculo ca. $1 \mathrm{~cm}$; receptáculo paleáceo, páleas oblanceoladas; invólucro campanulado, ca. $4 \times 6 \mathrm{~mm}$, brácteas externas expandidas, 
ovadas, pubescentes, ápice obtuso, margem ciliada, internas envolvendo as cipselas das flores do raio, lanceoladas, glabras, ápice agudo. Flores do raio 5-7; corola tubulosa, alva, ca. 1 mm compr., pubescente, pontuada de glândulas, ápice 3lobado. Cipsela ca. $6 \mathrm{~mm}$ compr., pontuada de glândulas, tricomas uncinados, enegrescidas; papilho ausente. Flores do disco funcionalmente masculinas, 12-14, corola tubulosa, alva, $2 \mathrm{~mm}$ compr., pubescente, pontuada de glândulas, ápice 5-lobado; anteras enegrescidas. Cipsela estéril, pontuada de glândulas; papilho ausente.

Material examinado: Viçosa, MP, Trilha principal, 6.XII.1989, fl. e fr., M. Thiengo 61 (VIC).

Floresce em dezembro. Distribui-se no sul daAmérica do Norte, Caribe, Colômbia, Venezuela, Guianas, Bolívia, Paraguai, Uruguai e Brasil, estando distribuída por todos os estados brasileiros (Nakajima 2000).

2. Achyrocline satureioides (Lam.) DC., Prodr. 6: 220. 1837.

Fig. 2b

Gnaphalium satureioides Lam., Encycl. 2: 747.1788.

Ervas, ca. 1,2 m alt.; caule cilíndrico, levemente estriado, albo-seríceo. Folhas membranáceas a cartáceas, linear-lanceoladas, 4,1-7,1 $\times 0,3-0,5 \mathrm{~cm}$, discolores, ambas as faces seríceas, margem inteira, base atenuada, sésseis. Capítulos disciformes, dispostos em panículas corimbiformes, sésseis; receptáculo plano, glabro, epaleáceo; invólucro cilíndrico, 4,5×1,5 mm; brácteas involucrais 9-10, amarelas, ovadas, externas gradualmente menores, ápice agudo. Flores marginais 4, pistiladas, filiformes, amarelas, corola 1,5-3 mm compr., glabra, lobos papilosos. Flor central 1, hermafrodita, amarela, corola 2-3 mm compr., glabra, lobos papilosos; anteras com apêndice lanceolado, base caudada; ramos do estilete com duas áreas estigmáticas distintas, truncados, penicilados. Cipsela oblonga ca. $2 \mathrm{~mm}$ compr., glabra, com epiderme papilosa; papilho unisseriado, 1,5-2 mm compr., cerdas livres, caducas, palhete.

Material examinado: Viçosa, MP, Trilha principal, 29.XI.1989, fl. e fr., M. Thiengo 50 (VIC).

Floresce em novembro. Amplamente distribuída na América do Sul (Nakajima 2000).
3. Adenostemma brasilianum (Pers.) Cass., Dict. Sci. Nat. 25: 363. $1822 . \quad$ Fig. 2c-d Verbesina brasiliana Pers., Syn. Pl. 2: 472. 1807.

Ervas anuais, 0,6-1,2 m altura. Ramos achatados, fistulosos, estriados, pubescentes. Folhas opostas, membranáceas, hastadas, 5,1$23,5 \times 2,1-18,1 \mathrm{~cm}$, discolores, glabras em ambas as faces, ápice agudo a acuminado, margem irregularmente crenado-denteada, base subcordada, decorrente no pecíolo. Capítulos discóides, dispostos em panícula de cimeiras corimbiformes; receptáculo convexo, glabro; invólucro campanulado, ca. $6 \times 6 \mathrm{~mm}$; brácteas involucrais 17-18, dispostas em 2 séries, oblongas, glabras, margem ciliada, ápice obtuso. Flores hermafroditas, tubulosas, 30-35; corola ca. 2,5 mm, pubescente, lobos pubescentes; anteras com apêndice conspícuo, base obtusa; ramos do estilete brancos, fortemente claviformes, muito longos, base não dilatada. Cipsela obovóide, ca. 2 mm compr., glandulosa, com tricomas estipitados, 3-costado; papilho ca. $5 \mathrm{~mm}$, com três protuberâncias claviformes, duas maiores e uma menor, viscosas.

Material examinado: Viçosa, MP, 23.V.1978, fl. e fr., Fontella et al. 1056 (VIC); Sede, no torno em área aberta, 24.I.2005, fl., S.C. Ferreira \& I. Rodrigues 45 (VIC); 6.IV.2005, fl., S.C. Ferreira 95 (VIC); Trilha no interior da mata, 25.I.2005, fl., S.C. Ferreira \& I. Rodrigues 53 (VIC); 1.IV.2005, fl., S.C. Ferreira \& L.C.P. Lima 92 (VIC); 1.IV.2005, fl., S.C. Ferreira \& L.C.P. Lima 93 (VIC); 19.I.2005, fl., M. Thiengo 82 (VIC); Trilha principal, 3.II.2005, fl., S.C. Ferreira \& L.C.P. Lima 62 (VIC); 10.III.2005, fl. e fr., M. Godinho \& M.F. Vieira (VIC 29191).

Floresce de janeiro a maio. Distribui-se na Argentina, Bolívia, Uruguai e Brasil (King \& Robinson 1987), podendo serencontrada em Minas Gerais, Espírito Santo, Rio de Janeiro, Santa Catarina e Rio Grande do Sul (Baker 1876).

4. Ageratum conyzoides L., Sp. Pl. 2: 839. 1753.

Fig. 2e-f

Erva anual, ca. $50 \mathrm{~cm}$ compr., ereta; ramos cilíndricos, fistulosos, vináceos quando jovens, alvo-tomentosos. Folhas opostas, membranáceas, ovadas, 4,8-7,5 ×2,4-4,8 cm, concolores, ambas as faces esparsamente 


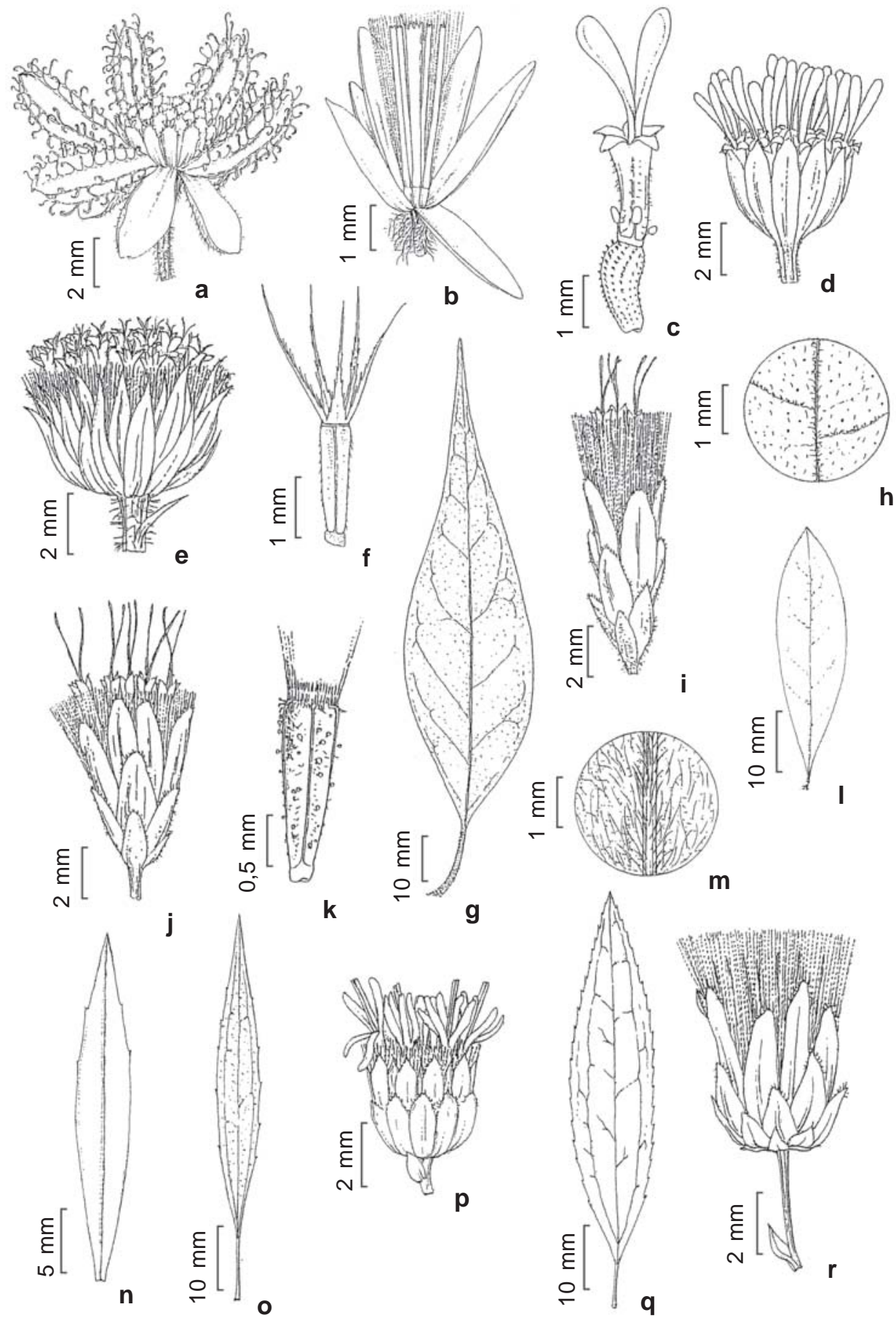

Figura 2 - a. Acanthospermum australe - a. capítulo. b. Achyrocline satureioides - b. capítulo. c-d. Adenostemma brasilianum - c. flor; d. capítulo. e-f. Ageratum conyzoides - e. capítulo; f. cipsela com papilho. g-i. Austrocritonia velutina - g. folha; h. indumento da face adaxial da lâmina foliar; i. capítulo. j-k. Austroeupatorium inulaefolium - j. capítulo; k. cipsela. 1-m. Baccharis calvensis - 1. folha; m. indumento. n. Baccharis dracunculifolia - n. folha. o-p. Baccharis medullosa - o. folha; p. capitulo. q-r. Baccharis microdonta - q. folha; r. capítulo.

Figure 2 - a. Acanthospermum australe - a. head. b. Achyrocline satureioides - b. head. c-d. Adenostemma brasilianum - c. flower; d. head. e-f. Ageratum conyzoides - e. head; f. cypselae with pappus. g-i. Austrocritonia velutina - g. leaf; h. indument of the abaxial face of the leaf; i. head. j-k. Austroeupatorium inulaefolium - j. head; k. cypselae. 1-m. Baccharis calvensis - 1. leaf; m. indumenta. n. Baccharis dracunculifolia - n. leaf. o-p. Baccharis medullosa - o. leaf; p. head. q-r. Baccharis microdonta - q. leaf; r. head. 
vilosas, 3-trinérvias, ápice agudo a acuminado, margem crenada, subcordada a truncada, pecíolo 1-3 cm, hirsuto a viloso. Capítulos homógamos, discóides, dispostos em cimas corimbiformes, pedunculados; receptáculo cônico, glabro; invólucro $4 \times 3 \mathrm{~mm}$, brácteas 18-20, dispostas em 2 séries, lanceoladas, esparsamente pubescentes ou glabras, ápice agudo a acuminado, fimbriado, margem inteira. Flores hermafroditas, 54-55; corola tubulosa, lilás, ca. $2 \mathrm{~mm}$, pontuada de glândulas, lobos pubescentes; anteras com apêndice apical conspícuo, base obtusa; ramos dos estilete longos, lineares, base do estilete não dilatada. Cipsela 1,5-2 mm, glabra, 5-costada; papilho ca. 2mm, escabroso, 4-5 aristas, unidas na base.

Material examinado: Viçosa, MP, Área do pomar de Citrus, 18.IV.2001, fl. e fr, H.G. de Castro (VIC 25.810); Trilha da lagoa menor, 12.V.2005, fl., S.C. Ferreira 109 (VIC); Trilha principal, próxima a entrada da reserva, 24.I.2005, fl., S.C. Ferreira \& I. Rodrigues 50 (VIC).

A espécie floresce de janeiro a maio. Amplamente distribuída, ocorrendo no México, América Central, Antilhas e América do Sul (Cabrera 1963). Baker (1876) citou a espécie como invasora.

5. Austrocritonia velutina (Gardner) R.M. King \& H. Rob., Phytologia 31(1): 117. 1975.

Fig. 2g-i

Eupatorium velutinum Gardner, London J. Bot. 5: 473. 1846.

Arvoreta, 2-8 m; ramos jovens cilíndricos, levemente estriados, tomentosos. Folhas opostas, membranáceas, elípticas a lanceoladas, 6,1$14,1 \times 1,5-4,2 \mathrm{~cm}$, discolores, face adaxial esparso serícea, face abaxial densamente serícea, ambas as faces pontuadas de glândulas, peninérvias, ápice agudo a acuminado, margem inteira, base cuneada a atenuada, pecíolo $1,5-2,8 \mathrm{~cm}$ compr., tomentoso. Capítulos homógamos, discóides, dispostos em cimeiras corimbiformes congestas, sésseis; receptáculo ligeiramente convexo, glabro; invólucro cilíndrico-campanulado, ca. $9 \times 3 \mathrm{~mm}$, brácteas involucrais 14-15, dispostas em 4 séries, externas ovadas, pubescentes, internas glabras, margem ciliada, ápice obtuso. Flores hermafroditas, 5; corola tubulosa, branca, ca. $6 \mathrm{~mm}$ compr., glabra, lobos 2 vezes mais compridos que largos, glabros; antera com apêndice conspícuo, base obtusa; ramos do estilete longos, lineares, base não dilatada, glabra. Cipsela ca. 3mm compr., glabra, 5costada; papilho 5-6 mm compr., palhete.

Material examinado: Viçosa, MP, Trilha principal do aceiro, 12.IX.2004, fr., S.C. Ferreira et al. 25 (VIC); 12.IX.2004, fr., S.C. Ferreira et al. 26 (VIC).

Material adicional examinado: Viçosa, Escola Superior de Agricultura, 10.IX.1930, fl., Y. Mexia 4947 (VIC).

Floresce de setembro a novembro. No Brasil, é encontrada em Goiás, Minas Gerais, Rio de Janeiro (Itatiaia) e São Paulo (Barroso 1950; Esteves 2001).

6. Austroeupatorium inulaefolium (Kunth) R.M. King \& H. Rob., Phytologia 19: 434. 1970.

Fig. $2 \mathrm{j}-\mathrm{k}$

Eupatorium inulaefolium Kunth. in H.B.K., Nov. Gen. Sp. Pl. 4: 85. 1818.

Subarbusto ereto, ca. $1,8 \mathrm{~m}$; ramos cilíndricos, estriados, tomentosos, tricomas alvos, pontuados de glândulas. Folhas opostas, cartáceas, linear-lanceoladas ou estreitamente ovadas, 4,5-9,7 × 1,5-3,2 cm, discolores, face adaxial estrigosa, pontuada de glândulas, face abaxial tomentosa, tricomas alvos, densamente pontuada de glândulas, triplinérvia, ápice acuminado, irregularmente serreada, base cuneada, pecíolo ca. $1 \mathrm{~cm}$ compr., tomentoso, pontuado de glândulas. Capítulos homógamos, discóides, dispostos em panículas de cimeiras corimbiformes; receptáculo plano, glabro; invólucro campanulado, ca. $5 \times 2 \mathrm{~mm}$, brácteas involucrais 15-16, dispostas em 3-4 séries desiguais em comprimento, externas gradualmente menores, todas oblongas, glabras, palhetes, ápice obtuso. Flores hermafroditas, 9-10; corola tubulosa, branca, ca. $4 \mathrm{~mm}$ compr., glabra, lobos esparsamente pubescentes, pontuados de glândulas; anteras com apêndice apical conspícuo, base obtusa; ramos do estilete longos, lineares, base não dilatada. Cipsela 1,5-2 mm compr., glabra, pontuada de glândulas, 5-costada; papilho ca. 4 mm compr., alvo. 
Material examinado: Viçosa, MP, Trilha principal, em frente à trilha dos Gigantes, 3.V.2005, fl., S.C. Ferreira 106 (VIC); 14.VI.2005, fr., S.C. Ferreira 128 (VIC).

Floresce em maio e junho, apresentando borboletas como visitantes florais. Apresenta ampla distribuição, ocorrendo das Antilhas até o centro da Argentina (Cabrera \& Klein 1989). No Brasil amplamente distribuída, exceto na região norte (Esteves 2001).

7. Baccharis L., Sp. Pl. 860. 1753.

Subarbustos, arbustos ou raramente arvoretas, dióicos; ramos folhosos, áfilos ou providos de alas foliáceas. Folhas alternas ou raramente opostas. Capítulos discóides; invólucro campanulado ou cilíndrico, brácteas involucrais em 3-8 séries. Flores masculinas com corola tubulosa, 5-lobada, tubo gradativamente ampliado em direção ao ápice, lobos espiralados ou revolutos; ramos do estilete curtos ou conados, com ápice espessado, pilosos; rudimento do ovário curto; papilho 1-seriado de cerdas escabras, onduladas ou crespas na base, ápice espessado ou não. Flores pistiladas com corola filiforme, ápice truncado, denteado ou fimbriado; ramos do estilete exsertos, lineares. Cipsela comprimida, 5-costada ou cilíndrica, 10-12 costada; papilho 1-multisseriado, cerdas capilares.

\section{Chave para as espécies de Baccharis ocorrentes na MP}

1. Ramos alados, capítulos sésseis

6. B. trimera

1'. Ramos não alados, capítulos pedunculados.

2. Lâmina foliar com padrão de venação uninérvia, margem revoluta.

3. Lâmina foliar discolor, tomentosa na face abaxial, pubescente na face adaxial .. 1. B. calvensis

3'. Lâmina foliar concolor, ambas as faces glabras ...................... 2. B. dracunculifolia

2'. Lâmina foliar com padrão de venação trinérvia ou triplinérvia, margem nunca revoluta

4. Plantas com caule fistuloso, lâmina foliar com padrão de venação 3-nérvia (3-nervada desde praticamente a base).

5. Plantas densamente ramificadas, margem foliar inteira, base cuneada, capítulos dispostos em panículas, receptáculo dos capítulos femininos paleáceo

7. B. trinervis

5'. Plantas pouco ramificadas, margem foliar serreada, base atenuada, capítulos dispostos em corimbos, receptáculo dos capítulos femininos epaleáceo ....

3. B. medullosa

4'. Plantas com caule não fistuloso, lâmina foliar com padrão de venação 3-plinérvia (3nervada distintamente acima da base).

6. Face abaxial da lâmina foliar pontuada de glândulas, brácteas involucrais externas ovadas, capítulos femininos com até 50 flores, ramos do estilete das flores masculinas separados

5. B. serrulata

6'. Face abaxial da lâmina foliar sem pontuações glandulares, brácteas involucrais externas oblongas, capítulos femininos com mais de 50 flores, ramos do estilete das flores masculinas conados

4. B. Microdonta

7.1. Baccharis calvensis DC., Prodr. 5: 413. 1836.

Fig. 21-m

Subarbustos, 1,5-1,7 $\mathrm{m}$ alt., ereto, densamente ramificado; caule cilíndrico, estriado, não fistuloso, pubescente a tomentoso.
Folhas membranáceas, elípticas a lanceoladas, $1,8-5,1 \times 0,6-1,2 \mathrm{~cm}$, discolores, face adaxial pubescente, face abaxial tomentosa, ambas as faces pontuadas de glândulas, venação 1nérvia, ápice acuminado, margem inteira, 
revoluta, base atenuada, pecíolo 1-5 $\mathrm{mm}$ compr., tomentoso. Capítulos dispostos em panícula, pedunculados. Capítulos estaminados com invólucro ca. $4 \times 3,5 \mathrm{~mm}$; brácteas involucrais dispostas em 3-4 séries, internas lanceoladas, externas ovadas, pubescentes, ápice agudo, margem 1/3 superior ciliada; receptáculo convexo; flores 28-35; corola ca. 2,5 mm compr., esparsamente pontuada de glândulas, lobos lanceolados, revolutos; estilete ca. $2 \mathrm{~mm}$ compr., ramos conados, espessados no ápice, triangulares; papilho ca. 2,5 mm compr., flexuoso, alvo. Capítulos pistilados com invólucro ca. $5 \times 2 \mathrm{~mm}$, brácteas involucrais dispostas em 3-4 séries, internas lanceoladas, externas ovadas, glabro, ápice agudo; receptáculo convexo; flores 40-42; corola ca. $3 \mathrm{~mm}$ compr., pilosa, ápice fimbriado; estilete ca. 4 mm compr., ramos cilíndricos, agudos no ápice. Cipsela1 mm compr., glabra; papilho ca. $3 \mathrm{~mm}$ compr., cerdoso, alvo.

Material examinado: Viçosa, MP, Trilha principal, 22.VII.2005, fl., ơ, S.C. Ferreira \& D. Francino 136(VIC). Material adicional examinado: Itapecerica, 6.VI.2001, fl., 오, E. Teixeira \& A.J. de Carvalho (VIC 26.905); Viçosa, Escola Superior de Agronomia, 26.VIII.1964, fl. e fr., , M.R. Vidal 270 (VIC).

Floresce em maio. A espécie encontrase distribuída da Bahia até Santa Catarina (Barroso 1976).

\subsection{Baccharis dracunculifolia DC., Prodr.}

\section{5:421. 1836.}

Fig. 2n

Subarbustos, 1,5-2 $\mathrm{m}$ alt., eretos, densamente ramificados; caule estriado, não fistuloso, tomentoso. Folhas subcoriáceas, lanceoladas ou oblanceoladas, 1-3,2 $\times 0,2-$ $1 \mathrm{~cm}$, concolores, ambas as face glabras, pontuadas de glândulas, venação 1-nérvia, ápice agudo, margem inteira ou 1-3 denteada, revoluta, base atenuada, sésseis. Capítulos dispostos em panícula, localizados nas axilas das folhas, pedunculados. Capítulos estaminados com invólucro campanulado, ca. $3,5 \times 3 \mathrm{~mm}$, brácteas involucrais dispostas em 3 séries, internas lanceoladas, externas ovadas, glabras, ápice agudo, margem hialina; receptáculo convexo; flores 28-30; corola ca.
$3 \mathrm{~mm}$ compr., pilosa, lobos revolutos; estilete ca. $3 \mathrm{~mm}$ compr., ramos conados, triangulares; papilho ca. $3 \mathrm{~mm}$ compr., cerdoso, alvo. Capítulos pistilados com invólucro ca. 4,5 ×3 $\mathrm{mm}$, brácteas involucrais dispostas em 3 séries, internas lanceoladas, externas ovadas, glabra, ápice agudo, margem hialina, receptáculo convexo; flores 32-34; corola ca. $2 \mathrm{~mm}$ compr., pilosa, ápice denteado; estilete ca. $4 \mathrm{~mm}$ compr., ramos cilíndricos, agudos no ápice. Cipsela ca. 1mm compr., glabra; papilho ca. 5 mm compr., cerdoso, alvo.

Material examinado: Viçosa, MP, Capinzal acima da lagoa, 4.X.1989, fl., ㅇ, M.Thiengo 29 (VIC); Trilha do aceiro, 16.V.2005, fl, ox, S.C. Ferreira \& I. Rodrigues 113 (VIC); 06.VI.2005, fl., ox, S.C. Ferreira et al. 125. (VIC); Trilha principal, 25.III.1984, fl., , E.A. Ferreira (VIC 8.683); 26.V.2005, fl., o ${ }^{\star}$, S.C. Ferreira \& L.C.P. Lima 119 (VIC); 26.V.2005, fl. e fr., ㅇ, S.C. Ferreira \& L.C.P. Lima 120 (VIC).

Floresce de março a outubro. Distribuída por toda Região Sudeste do Brasil e na Argentina (Barroso 1976).

7.3. Baccharis medullosa DC., Prodr. 5: 421. 1836.

Fig. 2o-p

Subarbustos, ca. 2,5 m alt., ereto, pouco ramificado; caule estriado, fistuloso, glabrescente. Folhas membranáceas, lanceoladas, 2,5-7,1 $\times$ $0,2-0,7 \mathrm{~cm}$, concolores, ambas as face glabras, pontuadas de glândulas, venação 3-nérvia, ápice acuminado, margem serrulada, base atenuada, pecíolo 0,5-1,5 cm compr., glabro. Capítulos dispostos em corimbo, pedunculados. Capítulos estaminados com invólucro campanulado, ca. $4 \times 4 \mathrm{~mm}$, brácteas involucrais dispostas em 3 séries, internas lanceoladas, externas ovadas, glabras, ápice agudo, margem hialina; receptáculo convexo; flores ca. 50; corola ca. $3 \mathrm{~mm}$ compr., glabro, lobos lanceolados, inflexos; estilete ca. 3 mm compr., ramos conados, agudos, espessados no ápice; papilho ca. $3 \mathrm{~mm}$ compr., cerdoso, alvo. Capítulos pistilados com invólucro campanulado, receptáculo convexo; flores ca. 100; corola ca. $1 \mathrm{~mm}$ compr., ápice truncado, fimbriado; estilete 3,5-4 mm compr. Cipsela 1,5 mm compr., papilosas.

Material examinado: Viçosa, MP, Margem da lagoa principal, 29.XI.1989, fl., ơ, M. Thiengo 52 (VIC). 
Floresce em novembro. No Brasil ocorre de Pernambuco até Santa Catarina; podendo ser encontrada também na Argentina, Uruguai, Bolívia e Paraguai (Barroso 1976).

7.4. Baccharis microdonta DC., Prodr. 5: 416. 1836. Fig. 2q-r

Arbustos, 1,3-3 m alt., eretos, densamente ramificados desde a base; caule estriado, não fistuloso, glabrescente. Folhas coriáceas, lanceoladas, 2,5-7,2×0,4-1,1 cm, discolores, ambas as face glabras, venação 3-plinérvia, ápice agudo, margem 2/3 distal curtamente denteada, base atenuada, pecíolo com até 0,5 cm compr., glabro. Capítulos dispostos em panícula, pedunculados. Capítulos estaminados com invólucro campanulado, ca. 4,5 ×4 mm, brácteas involucrais dispostas em 3 séries, internas lanceoladas, externas oblongas, pubescentes, ápice agudo, margem ciliada; receptáculo convexo; flores 20-21; corola ca. $4 \mathrm{~mm}$ compr., pilosa, lobos lanceolados, revolutos; estilete ca. $6 \mathrm{~mm}$ compr., ramos conados, triangulares; papilho ca. $4 \mathrm{~mm}$ compr., flexuoso, alvo. Capítulos pistilados com invólucro ca. $5 \times 3,5 \mathrm{~mm}$, brácteas involucrais dispostas em 3 séries, internas lanceoladas, externas oblongas, pubescentes, ápice agudo, ciliado; margem hialina, receptáculo convexo; flores 80-110; corola ca. 2,5 mm compr., glabra, ápice truncado, fimbriado; estilete ca. $5 \mathrm{~mm}$ compr., ramos cilíndricos, agudos no ápice. Cipsela 1-1,5 mm compr., glabra; papilho ca. $5 \mathrm{~mm}$ compr., cerdoso, alvo.

Material examinado: Viçosa, MP, Trilha do aceiro, 12.XI.2004, fl., ơ, S.C. Ferreira et al. 27(VIC); Capinzal acima da lagoa; 5.I.1990, fl., o ${ }^{\top}$, M. Thiengo 65 (VIC); Trilha principal, 5.I.1990, fl., o, M.Thiengo 71 (VIC); 3.I.1990, fl., fr., \&, M. Thiengo 75 (VIC).

Floresce de novembro a janeiro. No Brasil encontra-se distribuída desde Minas Gerais até o Rio Grande do Sul, podendo ser encontrada também na Argentina (Barroso 1976).

7.5. Baccharis serrulata Pers., Syn. Plant. 2: 423.1807.

Fig. 3a-c

Subarbusto, 0,4-1,8 m alt., ereto, pouco ramificado; caule estriado, não fistuloso, tomentoso. Folhas membranáceas, ovadas ou lanceoladas, 3,9-7,3 × 1-2,8 cm, discolores, ambas as faces glabrescentes, face abaxial pontuada de glândulas, venação 3-plinérvia, ápice agudo, margem serreada, base atenuada, pecíolo 0,7-1,5 cm compr., tomentoso. Capítulos dispostos em corimbo, pedunculados. Capítulos estaminados com invólucro campanulado, ca. 4,5 $\times 4 \mathrm{~mm}$, brácteas involucrais dispostas em 3 séries, internas lanceoladas, externas ovadas, pubescentes, pontuada de glândulas, ápice agudo, margem com ápice ciliado; receptáculo convexo; flores 17-25; corola ca. 2 mm compr., pilosa, lobos lanceolados, revolutos; estilete ca. 2,5 mm compr., ramos separados, triangulares; papilho ca. $2 \mathrm{~mm}$ compr., cerdoso, alvo. Capítulos pistilados com invólucro ca. $3,5 \times 3 \mathrm{~mm}$, brácteas involucrais dispostas em 3 séries, internas lanceoladolineares, externas ovadas, pubescentes, ápice agudo; margem com ápice ciliado, receptáculo convexo; flores 35-44; corola ca. 2 mm compr., pilosa, ápice truncado, fimbriado; estilete ca. 3 mm compr., ramos cilíndricos, agudos no ápice. Cipsela ca. $1 \mathrm{~mm}$ compr., pubescente; papilho ca. $3 \mathrm{~mm}$ compr., cerdoso, alvo.

Material examinado: Viçosa, MP, 25.XI.2002, fl., o", P.B. de Souza (VIC 29.520); Trilha do aceiro, 8.XI.2004, fl., ㅇ, S.C. Ferreira \& L.A. Basilio 22 (VIC); 16.V.2005, fl., ơ, S.C. Ferreira \& I. Rodrigues 115 (VIC); Trilha principal, 12.X.1989, fl., o $\sigma^{\pi}$, M. Thiengo 12 (VIC); 30.X.1989, fl. e fr., ㅇ, M. Thiengo 42 (VIC).

Floresce de maio a novembro. Ocorre de Pernambuco até o Rio de Janeiro, sendo muito comum em Minas Gerais (Barroso 1976).

7.6. Baccharis trimera (Less.) DC., Prodr. 5: 425.1836. Fig. 3d

Molina trimera Less., Linnaea 6: 141. 1831.

Subarbusto, $60-80 \mathrm{~cm}$, prostado, ramificado; caule alado, alas com até $2 \mathrm{~cm}$ larg., liso, não fistuloso, pubérulo. Folhas caducas, subcoriáceas, ovadas, reduzidas, com até $1,1 \times 0,6 \mathrm{~cm}$, concolores, ambas as faces glabras, ápice agudo, margem inteira, base cordada, sésseis. Capítulos dispostos em panícula, sésseis. Capítulos estaminados com invólucro campanulado, ca. $4 \times 3 \mathrm{~mm}$, brácteas involucrais dispostas em 
4-5 séries, internas lanceoladas, externas ovadas, pubescentes, ápice agudo, margem inteira; receptáculo convexo; flores 30-34; corola ca.3,5 mm compr., glabra, lobos lanceolados; estilete ca. 4 mm compr., ramos conados, triangulares; papilho ca. $3 \mathrm{~mm}$ compr., flexuoso, alvo. Capítulos pistilados com invólucro ca. $6 \times 4,5 \mathrm{~mm}$, brácteas involucrais dispostas em 3 séries, internas lanceoladas, externas ovadas, pubescentes, ápice agudo, margem inteira; receptáculo convexo; flores 90-105; corola ca. $3 \mathrm{~mm}$ compr., glabra, ápice truncado; estilete ca. 4,5 mm compr., ramos cilíndricos, agudos no ápice. Cipsela ca. $1 \mathrm{~mm}$ compr., glabra; papilho ca. 3,5 mm compr., cerdoso, alvo ou rosado.

Material examinado: Viçosa, MP, Trilha principal, 12.V.1984, fl., ơ, E.A. Ferreira (VIC 8.690);22.VII.2005, fl., ㅇ, S.C. Ferreira \& D. Francino 135 (VIC).

Material adicional: BRASIL. MINAS GERAIS: Itapecerica, 03.IV.2001, fl., 우, E. Teixeira \& D. Message (VIC 26.907); 8.VI.2001, fl., +, E. Teixeira \& A.J. de Carvalho (VIC 26910).

Floresceu de maio a julho. No Brasil encontra-se amplamente distribuída, ocorrendo de Minas Gerais até o Rio Grande do Sul, podendo ainda ser encontrada no Uruguai, Bolívia e Nordeste da Argentina (Barroso 1976).

\subsection{Baccharis trinervis Pers., Syn. Plant. 2:} 423. 1807.

Fig. 3e-f

Subarbustos, 0,5-2 $\mathrm{m}$ alt., eretos ou prostados, ramificados desde a base; caule estriado, fistuloso, glabrescente ou tomentoso. Folhas membranáceas, elípticas ou lanceoladas, $2,2-7,3 \times 1,1-2,3 \mathrm{~cm}$, concolores, ambas as faces glabras ou pubescentes, venação 3nérvia, ápice agudo ou agudo-mucronado, margem inteira, base cuneada, pecíolo 0,4-1 cm compr., glabrescente ou tomentoso. Capítulos dispostos em panícula, pedunculados. Capítulos estaminados com invólucro campanulado, ca. 3,5 × 2,5 mm, brácteas involucrais dispostas em 3 séries, internas lanceoladas, externas oblongas, pubescentes, ápice agudo, margem inteira; receptáculo convexo; flores 25-26; corola ca. 3,5 mm compr., glabra, lobos lanceolados, revolutos; estilete ca. 4,5 mm compr., ramos conados, triangulares, com ápice agudo; papilho ca. 3 mm compr., flexuoso, alvo. Capítulos pistilados com invólucro ca. $5 \times 3,5 \mathrm{~mm}$, brácteas involucrais dispostas em 3 séries, internas lanceoladas, externas oblongas, glabras, ápice agudo, margem inteira; receptáculo convexo, paleáceo; flores 140-150; corola ca. $3 \mathrm{~mm}$ compr., pubescente, ápice truncado, fimbriado; estilete ca. $6 \mathrm{~mm}$ compr., ramos cilíndricos, agudos no ápice. Cipsela 0,8-1 mm compr., pubescente; papilho ca. $5 \mathrm{~mm}$ compr., cerdoso, alvo.

Material examinado: Viçosa, MP, Margem da lagoa principal, 5.I.1990, fl., o, M. Thiengo 74 (VIC); Trilha do aceiro, 8.XI.2004, fl., o, S.C. Ferreira \& A.L. Basílio 19 (VIC); 8.XI.2004, fl., ơ, S.C. Ferreira \& A.L. Basilio 20 (VIC); Trilha principal, 3.II.2005, fl., , , S.C. Ferreira \& L.C.P.Lima 56 (VIC); 11.III.2005, fl., + , S.C. Ferreira 76 (VIC); 14.II.2005, fl., ㅇ, S.C. Ferreira \& D. Francino 66(VIC); 11.III.2005, fl., +, S.C. Ferreira 77 (VIC); 11.III.2005, fl., ơ, S.C. Ferreira 79 (VIC).

Floresce de novembro a março. Distribuise do México até o Sul do Brasil, Argentina e Paraguai (Barroso 1976).

\section{Bidens L., Gen. Pl. 5:362. 1754.}

Ervas anuais ou perenes, arbustos ou lianas. Folhas simples, opostas, raro verticiladas, geralmente dissectas, raramente inteiras, serreadas ou lobadas, pecioladas. Capítulos dispostos em corimbos ou panículas, heterógamos, radiados, ou homógamos, discóides, pedunculados, pedúnculos estriados, subtendidos por um par de brácteas ou 1-várias bractéolas foliáceas; invólucro campanulado, brácteas involucrais bisseriadas, externas verdes, as internas, estriadas, com margem hialina; receptáculo plano ou convexo, páleas similares as brácteas involucrais internas. Flores do raio neutras ou raramente pistiladas, unisseriadas ou ausentes; corola ligulada, geralmente 3-lobada, amarelas. Cipselas comprimidas dorsiventralmente. Flores do disco hermafroditas ou raramente funcionalmente masculinas; corola tubulosa, (4)-5-lobada, amarela; apêndice das anteras com ducto resinífero central, base obtusa ou subauriculada, filetes glabros; ramos do estilete 

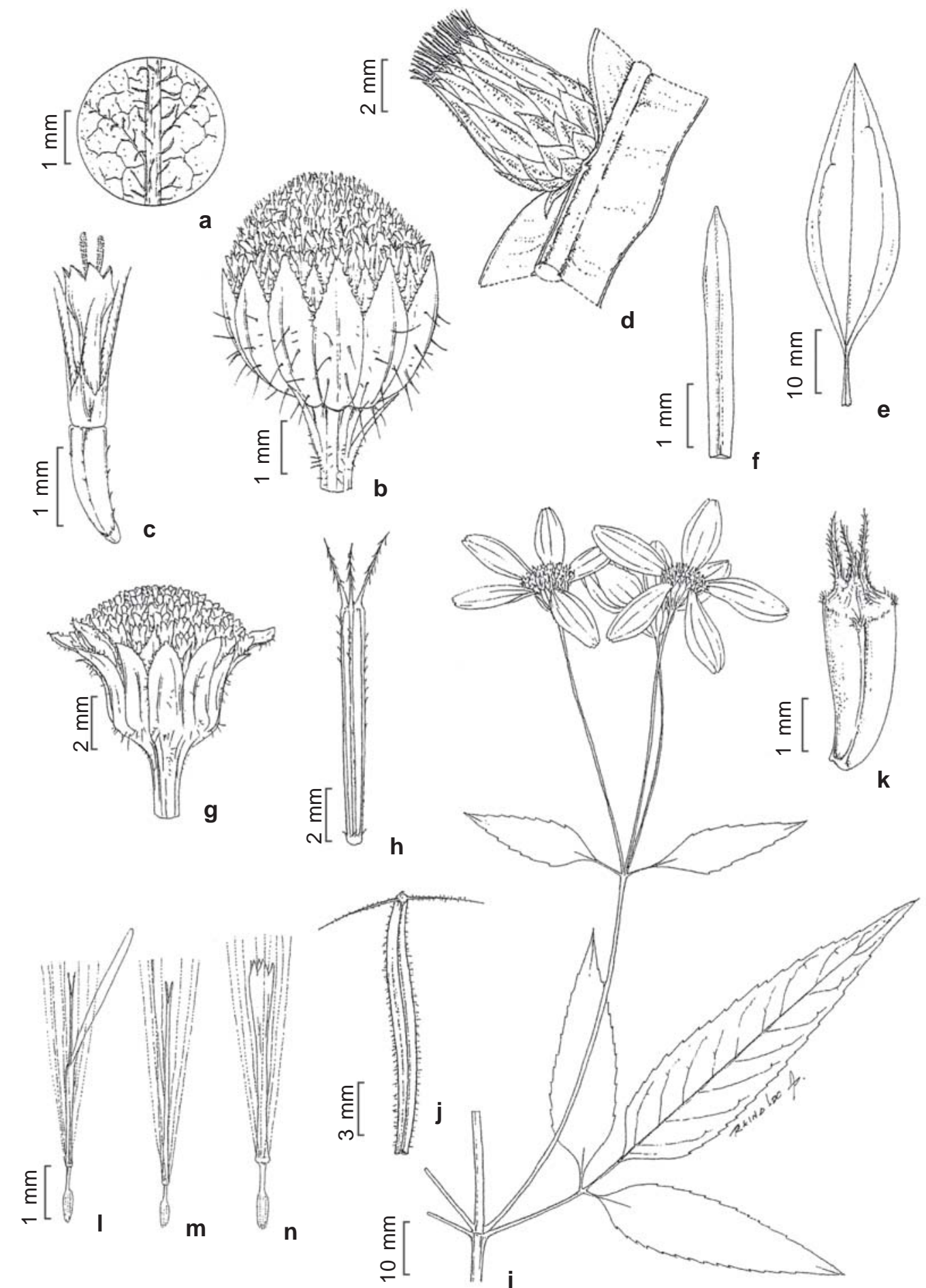

Figura 3 - a-c. Baccharis serrulata - a. detalhe da face abaxial da lâmina foliar; b. capitulo; c. flor. d. Baccharis trimera d. ramo com capítulo. e-f. Baccharis trinervis - e. folha; f. pálea. g-h. Bidens pilosa - g. capítulo; h. cipsela. i-j. Bidens segetum -i. ramo; j. cipsela. k. Blainvillea biaristata -k. cipsela. 1-n. Chaptalia nutans -1. flor do disco; m. flor interna; n. flor marginal.

Figure 3 - a-c. Baccharis serrulata - a. detail of the face abaxial of the leaf; b. head; c. flower. d. Baccharis trimera - d. branch with head. e-f. Baccharis trinervis - e. leaf; f. pale. g-h. Bidens pilosa - g. head; h. cypselae. i-j. Bidens segetum - i. branch with head; j. cypselae. k. Blainvillea biaristata - k. cypselae. 1-n. Chaptalia nutans - 1. disk flower; m. inner flower; n. marginal flower. 
achatados, com apêndice reduzido, piloso. Cipsela oblongo-linear a elipsóide, 3-4 angulosa ou comprimida, apicalmente estrigosa, às vezes alada; papilho de até 6 aristas e/ou cerdas, geralmente barbeadas ou com tricomas retrosos.

\section{Chave para as espécies de Bidens da MP}

1. Ervas eretas, flores do raio quando presentes diminutas, ca. $0,4 \mathrm{~cm}$ compr., papilho 3 -aristado 1. B. pilosa

1'. Subarbustos a arbustos decumbentes, flores do raio sempre presentes, conspícuas, ca. 2,2 cm compr., papilho 2-aristado

2. B. segetum

8.1. Bidens pilosa L., Sp. Pl. 2: 832. 1753.

Fig. 3g-h

Ervas 30-60 cm, eretas; caule tetragonal, estriado, esparso pubescente a glabro. Folhas 3-partidas, segmentos membranáceos, elípticos, 4,1-7,6×2,9-6,6 cm, ambas as faces glabrescentes, ápice agudo, margem serreada, base atenuada, pecíolo 2,2-4,5 $\mathrm{mm}$ compr. Capítulos dispostos em cimeiras, pedunculados, pedúnculos 3,5-8 cm compr.; invólucro ca. 6 $\times 5 \mathrm{~mm}$; brácteas externas oblanceoladas, pubescentes, ápice agudo, margem ciliada, internas lanceoladas, glabras, ápice agudo, pubescente; receptáculo convexo, páleas linear-lanceoladas. Flores do raio 4-5, pistiladas, diminutas ou ausentes; corola amarelo-claro, tubo ca. $2 \mathrm{~mm}$ compr., pubescente, limbo ca. $2 \times 2,5 \mathrm{~mm}$, glabro. Cipsela ca. $6 \mathrm{~mm}$ compr., pilosa. Flores do disco muitas, corola amarela, $3 \mathrm{~mm}$ compr., pubescente. Cipsela ca. $8 \mathrm{~mm}$ compr., tetragonal, pilosa; papilho 2-3 mm compr., com 3 aristas.

Material examinado: Viçosa, MP, Margem da lagoa menor, 3.II.2005, fl., S.C. Ferreira \& L.C. Pires Lima 60 (VIC); 12.V.2005, fl. e fr., S.C. Ferreira \& L.C. Pires-Lima 108(VIC); Trilha principal, 30.X.1989, fl. efr., M. Thiengo 39 (VIC); 25.XI.2002, fl., A.D. Koehler et al. (VIC 29.517).

Floresce durante todo o ano. Amplamente distribuída nas regiões tropicais e subtropicais (Cabrera 1963).

8.2. Bidens segetum Mart. ex Colla., Herb. Pedem. 3: 307. 1834. Fig. 3i-j

Subarbustos a arbustos ca. $3 \mathrm{~m}$ alt., decumbentes; caule cilíndrico, estriado, glabros, quando jovens tomentosos. Folhas simples ou 3-partida, raro 5-partida, segmentos membranáceos, lanceolados a ovados, terminal $6-14,5 \times 1,5-3,5 \mathrm{~cm}$, laterais 4,5-9,5 × 1,2$2,5 \mathrm{~cm}$, face adaxial pubescente, face abaxial tomentosa, ápice agudo a acuminado, margem serreada, base cuneada a atenuada, pecíolo 2,4-4,5 mm compr. Capítulos dispostos em cachos de dicásios, pedunculados, pedúnculos 2,8-7,8 cm compr.; invólucro ca. $0,7 \times 1 \mathrm{~cm}$, brácteas externas oblanceoladas, pubescentes, ápice agudo, margem ciliada, internas lanceoladas, glabras, ápice agudo, pubescente; receptáculo plano, páleas lanceoladas, hialinas. Flores do raio 5-8, pistiladas ou neutras; corola amarela, tubo ca. $2 \mathrm{~mm}$ compr., glabro, limbo ca. $2 \times 0,7 \mathrm{~cm}$, glabro, ápice obtuso. Cipsela ca. $3 \mathrm{~mm}$ compr., pilosa. Flores do disco muitas, corola amarela, $7 \mathrm{~mm}$ compr., glabra. Cipsela 4-6 mm compr., tetragonal, pilosa; papilho 3$4 \mathrm{~mm}$ compr., com 2 aristas.

Material examinado: Viçosa, MP, Margem da lagoa principal, 1.IV.2005, fl., S.C. Ferreira \& L.C. Pires Lima 87 (VIC); 14.VI.2005, fr., S.C. Ferreira et al. 127 (VIC); Trilha no interior da mata, 6.IV.2005, fl., S.C. Ferreira 94 (VIC); Trilha principal, 1.IV.2005, fl., S.C.Ferreira \& L.C. Pires-Lima 88 (VIC); 6.IV.2005, fl., S.C. Ferreira 97 (VIC).

Floresce de abril a maio. Distribui-se no Peru, Bolívia e Brasil, nos estados de Goiás, Minas Gerais e Paraná (Nakajima 2000).

9. Blainvillea biaristata DC., Prodr. 5: 492. 1836.

Fig. 3k

Ervas, anuais, ca. 1,6 m alt., eretas; caule cilíndrico, estriado, tomentoso. Folhas opostas, membranáceas, ovadas, 5,5-9,8 ×2,1-5,5 cm, 
face adaxial hirsuta, face abaxial setosa, ápice agudo, margem crenada a serreada, base atenuada, pecíolo 0,8-2,5 cm compr. Capítulos heterógamos, radiados, dispostos em panículas de dicásios, pedunculados, pedúnculos $2-5 \mathrm{~cm}$ compr., receptáculo paleáceo, convexo, páleas elípticas a lanceoladas, conduplicadas envolvendo as cipselas das flores do raio; invólucro ca. 6 $\times 5 \mathrm{~mm}$; brácteas 6 , oblongas, pubescentes, ápice obtuso, margem ciliada. Flores do raio com corola amarela, tubo ca. $2 \mathrm{~mm}$ compr., glabro, limbo ca. $1 \mathrm{~mm}$, 2-lobado, anteras enegrecidas. Cipsela enegrecida, ca. 4 mm compr., pilosa; papilho 2-3 aristado, aristas alargadas na base, tricomas retos.

Material examinado: Viçosa, MP, Margem da lagoa menor, 14.II.2005, fl., S.C. Ferreira \& D. Francino 69(VIC).

Floresce em fevereiro. Distribui-se no Paraguai, Uruguai, norte da Argentina e Região Sul do Brasil (Cabrera 1974). Baker (1884) referiu-se à espécie como ruderal.

10. Chaptalia nutans (L.) Polak., Linnaea 41:582.1877.

Fig. 31-n

Tussilago nutans L., Syst. Nat. 2: 1214. 1759.

Ervas, 32-60 cm alt. Folhas rosulado-basais, membranáceas, oblanceoladas, 6,1-27,2×2,9$6,2 \mathrm{~cm}$, discolores, face adaxial glabra, face abaxial albo-tomentosa, venação peninérvia, ápice agudo ou obtuso-apiculado, base atenuada, sésseis. Capítulos heterógamos, trimorfos, solitários, apicais, pêndulos quando jovens, eretos na antese; pedúnculo $24-55 \mathrm{~cm}$, ebracteado, densamente albo-tomentoso na região apical; receptáculo levemente convexo; invólucro cilíndricocampanulado, ca. 1,6-0,7 cm; brácteas involucrais em 4-5 séries, lanceoladas, tomentosas, ápice acuminado, avermelhado, margem inteira.
Flores marginais pistiladas, liguliformes, tubo ca. $9 \mathrm{~mm}$ compr., glabro, limbo ca. $4 \mathrm{~mm}$ compr., glabro, ápice 3-lobado. Flores internas pistiladas, filiformes, corola ca. $3 \mathrm{~mm}$, amareloclara. Flores do centro hermafroditas, tubulosas, tubo ca. $10 \mathrm{~mm}$ compr., glabro, lobo ca. $1 \mathrm{~mm}$ compr; estilete com pilosidade se estendendo abaixo do ponto de bifurcação. Cipsela rostrada, ca. $10 \mathrm{~mm}$, incluindo o rostro ca. $6 \mathrm{~mm}$, pubescente; papilho ca. $10 \mathrm{~mm}$, palhete.

Material examinado: Viçosa, MP, Trilha Circuito das Águas, 5.VIII.2005, fr., S.C. Ferreira \& E. Cabrini 157 (VIC); Trilha principal, 14.II.2005, fl., S.C. Ferreira \& D. Francino 65 (VIC); 25.VIII.2005, fl., S.C. Ferreira \& D. Francino 164 (VIC); 25.VIII.2005, fr., S.C. Ferreira \& D. Francino 165 (VIC).

Floresce praticamente ao longo de todo o ano. Ocorre do México até a Argentina (Cabrera 1963), sendo citada como planta ruderal por Barroso (1959). A espécie é abundante na MP, ocorrendo em pequenas populações, em locais úmidos, ao longo da trilha principal.

11. Chromolaena DC. Prodr. 5: 133. 1836.

Subarbustos ou arbustos eretos, raro escandentes. Folhas opostas, raro alternas. Capítulos homógamos, discóides, dispostos em panículas ou cimas corimbiformes densas ou laxas, raro isolados; receptáculo plano, glabro; invólucro cilíndrico, brácteas involucrais densamente subimbricadas, em (5-)6-8 séries, ocasionalmente caducas. Flores hermafroditas, mais de 5; corola tubulosa, subcilíndrica com tubo e limbo fracamente ou não diferenciados, lobos ligeiramente mais compridos que largos; anteras com apêndice apical conspícuo, obtusas na base; estilete com ramos longos, lineares ou distalmente dilatados, base não dilatada, glabra. Cipselas prismáticas, 5costadas, papilho de cerdas persistentes.

\section{Chave para identificação das espécies de Chromaloena da MP}

1. Ramos vernicosos, lâmina foliar com ambas as faces glabras, trinérvias (3-nervada praticamente desde a base), corola sem pontuações glandulares, ramos do estilete com ápice linear, cipsela glabra

1'. Ramos não vernicosos, lâmina foliar com ambas as faces pilosas, triplinérvia (3-nervada distintamente acima da base), corola com pontuações glandulares, ramos do estilete com ápice clavado; cipsela pilosa. 
2. Lâmina foliar subcoriácea, com pontuações glandulares na face abaxial; cipsela sem pontuações glandulares 3. C. squalida

2'. Lâmina foliar membranácea, sem pontuações glandulares na face abaxial; cipsela com pontuações glandulares

2. C. maximilianii

11.1. Chromolaena laevigata (Lam.) R.M. King \& H. Rob., Phytologia 20(3): 202.1970.

Fig. $4 a-b$

Eupatorium laevigatum Lam., Encycl. Meth.. 2:408. 1786.

Arbustos eretos, 1,8-2,5 m; ramos cilíndricos, estriados, vernicosos, glabros. Folhas opostas, cartáceas, elípticas ou oblanceoladas, 4,5-14,5 × 1,5-4,5 cm, ambas as faces glabras, face abaxial pontuada de glândulas, trinérvia, ápice agudo, margem serreada, base cuneada, pecíolo $0,5-1,3 \mathrm{~cm}$ compr., glabro. Capítulos dispostos em cima corimbiforme, pedunculados; invólucro cilíndrico, ca. $1,1 \times 0,3 \mathrm{~cm}$, brácteas involucrais 28-30, dispostas em 6-7, externas oblongas a arredondadas, internas lineares, glabras, ápice obtuso, ciliado. Flores 16-19 (26); corola lilás, ca. $6 \mathrm{~mm}$ compr., glabra, lobos glabros; ramos do estilete lineares. Cipsela ca. $3 \mathrm{~mm}$, glabras, 5-costada, costas ciliadas; papilho ca. $5 \mathrm{~mm}$ compr., alvo.

Material examinado: Viçosa, MP, Trilha circuito das caminhadas, 3.V.2005, fl. e fr., S.C. Ferreira 104 (VIC); Trilha principal, 6.IV.2005, fl., S.C. Ferreira 98(VIC); 14.IV.2005, fl. e fr., S.C. Ferreira \& L.C.P. Lima 100 (VIC).

Floresce em abril e maio, sendo suas flores visitadas por borboletas e vespas. Ocorre na América tropical e subtropical, desde o México até o norte da Argentina (Cabreira \& Klein 1989). No Brasil, pode ser encontrada em todas as regiões (Esteves 2001).

11.2. Chromolaena maximilianii (Schrad.) R.M. King \& H. Rob. Phytologia 49: 4. 1981.

Fig. 4c-e

Eupatorium maximilianii Schrad. ex DC., Prodr. 5: 143. 1836.

Subarbustos eretos, 1,2-1,6 m; ramos cilíndricos, estriados, glabrescentes, esparsamente seríceos em direção ao ápice. Folhas opostas, membranáceas, ovadas, 3,5-10,8 ×1,4-4,9cm, face adaxial esparso-estrigosa, face abaxial esparso-tomentosa, triplinérvia, ápice agudo, margem 2/3 inferior serreada, base cuneada, pecíolo 0,7-2,2 cm compr., tomentoso. Capítulos dispostos em cima corimbiforme, pedunculados; invólucro cilíndrico, ca. $1 \times 0,4$ $\mathrm{cm}$, brácteas involucrais 31-35, dispostas em 5-8 séries, externas oblongas, internas lineares, glabras, dorso sulcado, ápice obtuso. Flores 2829; corola lilás, ca. $6 \mathrm{~mm}$ compr., glabra, esparsamente pontuada de glândulas; ramos do estilete clavados. Cipsela ca. $5 \mathrm{~mm}$, pubescente, pontuada de glândulas, 5-costada; papilho ca. 5,5 mm compr., avermelhado.

Material examinado: Viçosa, MP, Trilha circuito das águas, 30.VI.2005, fr., S.C. Ferreira 134 (VIC); Trilha dos gigantes, 14.06.2005, fl., S.C. Ferreira et al.130 (VIC); 14.VI.2005, fl., S.C. Ferreira et al. 131 (VIC); Trilha principal do aceiro, 16.V.2005, fl., S.C. Ferreira \& I. Rodrigues 116(VIC); 6.VI.2005, fl., S.C. Ferreira et al. 121 (VIC); Trilha principal, próxima a entrada, 12.V.1984, fl., E.A. Ferreira (VIC 8688).

Floresce de maio a junho e em novembro. C. maximilianii é frequentemente confundida com C. odorata (L.) R.M. King \& H. Rob., espécie com ramos mais delgados, com tendência ao hábito apoiante, folhas geralmente mais estreitas, pontuada de glândulas na face abaxial, capítulos com 12-16 flores, invólucros e pedúnculos menores. Segundo Barroso (1950), a espécie encontra-se distribuída desde o México até a Argentina. No Brasil, ocorre desde Piauí até São Paulo (Esteves 2001).

11.3. Chromolaena squalida (DC) R.M. King \& H. Rob., Phytologia 20(3):206. 1970. Eupatorium squalidum DC., Prodr. 5: 142.1836.

Subarbustos eretos, $0,8-2 \mathrm{~cm}$; ramos cilíndricos, levemente estriados, castanhos, pubescentes. Folhas opostas, subcoriáceas, estreitamente ovadas a ovadas, $2,1-5,8 \times 1,2-2,9$ $\mathrm{cm}$, levemente discolores, face adaxial estrigosa, 

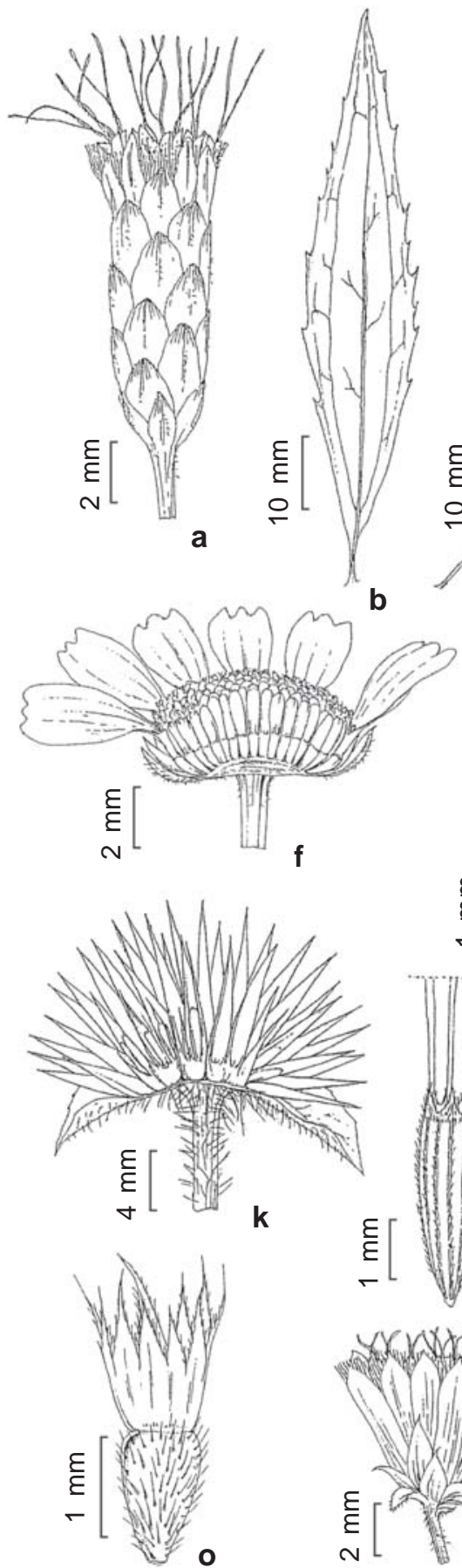
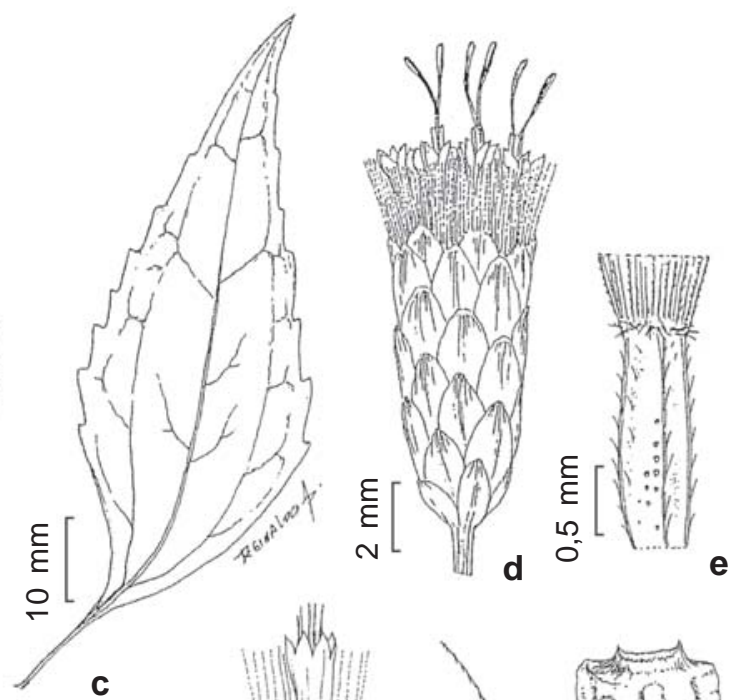

C
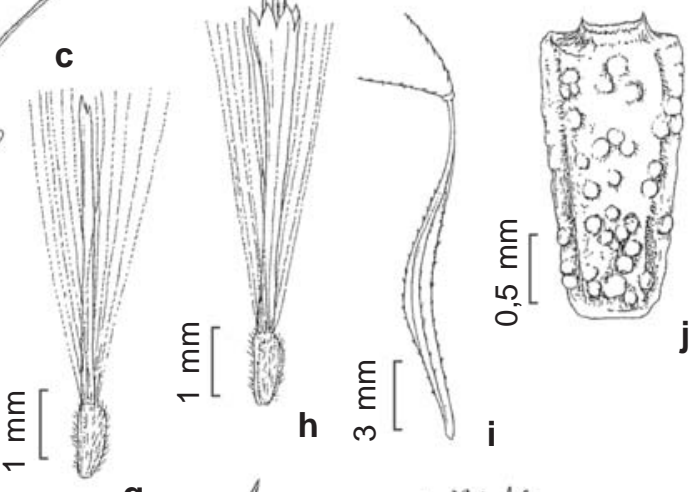

$\mathbf{h} \underset{\xi}{\varepsilon}[\sqrt{i}$

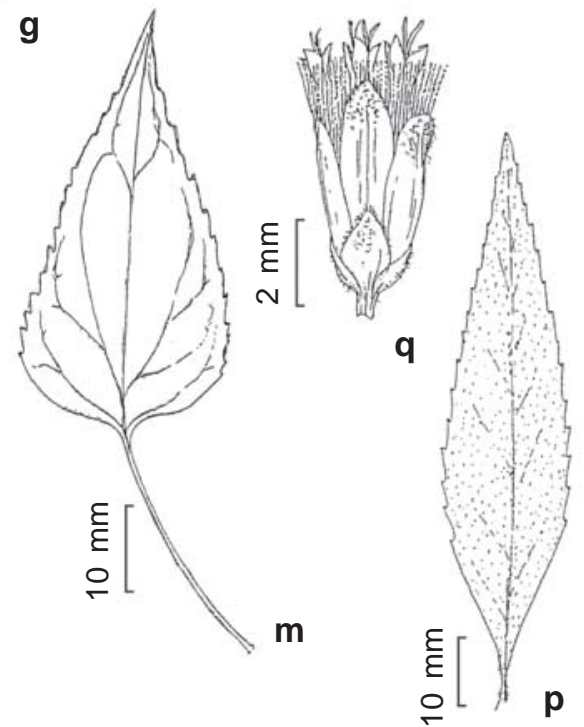

Figura 4 -a-b. Chromolaena laevigata - a. capítulo; b. folha. c-e. Chromolaena maximilianii -c. folha; d. capítulo; e. cipsela. f. Chrysanthemum parthenium -f. corte longitudinal do capítulo. g-h. Conyza bonariensis - g. flor do disco; h. flor do raio. i. Cosmos sulphureus - i. cipsela. j. Eclipta alba -j. cipsela. k-l. Elephantopus mollis - k. corte transversal da cooflorescência; 1. cipsela. m-n. Fleischmannia remotifolia - m. folha; n. capítulo. o. Galinsoga parviflora - o. cipsela. p-q. Grazielia intermedia - p. folha; q. capítulo.

Figure 4 - a-b. Chromolaena laevigata - a. head; b. leaf. c-e. Chromolaena maximilianii - c. leaf; d. head; e. cypselae. f. Chrysanthemum parthenium - f. cross-section head. g-h. Conyza bonariensis - g. disk flower; h. marginal flower. i. Cosmos sulphureus - i. cypselae. j. Eclipta alba - j. cypselae. k-1. Elephantopus mollis - k. cross-section cooflorescence; 1. cypselae. m-n. Fleischmannia remotifolia - m. leaf; n. head. o. Galinsoga parviflora - o. cypselae. p-q. Grazielia intermedia - p. leaf; q. head. 
face abaxial tomentosa, pontuada de glândulas, triplinérvia, ápice agudo ou obtuso mucronulado, margem serreada a crenada $2 / 3$ distal, base cuneada, pecíolo 3-6 mm compr., tomentoso, pontuado de glândulas. Capítulos dispostos em cimeiras corimbiformes, pedunculados; invólucro cilíndrico, 6-8×2,5-3 mm, brácteas involucrais 33-34, dispostas em 6-7 séries, externas ovadas a subarredondadas, internas lanceoladas, glabras, ápice obtuso, ciliado. Flores 19-25; corola lilás, ca. 4 mm compr., glabra, esparso pontuada de glândulas; ramos do estilete clavados. Cipsela ca. $3 \mathrm{~mm}$ compr., pilosa, pubescente, 5-costada; papilho ca. $4 \mathrm{~mm}$ compr., ferrugíneo.

Material examinado: Viçosa, MP, Lagoa principal, 11.IV.1990, fl., M. Thiengo 101 (VIC); Trilha principal do aceiro, 16.V.2005, fl., S.C. Ferreira \& I. Rodrigues 112 (VIC); 6.VI.2005, fr., S.C. Ferreira et al. 122 (VIC); 6.VI.2005, fl., S.C. Ferreira et al. 124 (VIC).

Floresce de abril a junho. Espécie amplamente distribuída na América do Sul (Moraes 1997). No Brasil, pode ser encontrada em Mato Grosso, Goiás, Minas Gerais, São Paulo, Paraná e Bahia (Barroso 1950).

12. Chrysanthemum parthenium (L.) Bernh., Syst. Verz. 145. 1800. Fig. $4 \mathrm{f}$ Matricaria parthenium L., Sp. Pl. 2: 890-891. 1753.

Ervas perenes, eretas; caule cilídrico, estriado, fistuloso, glabro. Folhas pinatissectas, membranáceas, $3,1-5,6 \times 1,8-4,2 \mathrm{~cm}$, segmentos elípticos, ambas as faces esparsamente pubescentes, ápice 3-lobado, margem irregularmente serreada, pecíolo 1-2 cm compr. Capítulos heterógamos, radiados, dispostos em panícula, pedunculados, pedúnculos até $4,5 \mathrm{~cm}$ compr.; receptáculo convexo, glabro; invólucro hemisférico, ca. 3 $\times 8 \mathrm{~mm}$, brácteas involucrais com canais resiníferos, dispostas em 2 séries, lanceoladas, pubescentes, pontuadas de glândulas, margem escariosa, ápice acuminado. Flores do raio 911; corola branca, tubo ca. $1 \mathrm{~mm}$ compr., glabro, limbo ca. 4 mm compr., pontuado de glândulas, 3-lobado. Cipsela ca. $1 \mathrm{~mm}$ compr., pontuada por glândulas inconspícuas. Flores do disco 98112, corola amarela, ca. 2 mm compr., glabra; ápice dos lobos com canais resiníferos. Cipsela ca. $1 \mathrm{~mm}$ compr., pontuada por glândulas inconspícuas; papilho ausente.

Material examinado: Viçosa, MP, Entrada da Reserva, 15.V.1983, fl., E.A. Ferreira (VIC 8680).

Floresce em maio. Originária do Velho Mundo e cultivada como ornalmental em todo mundo (Cabrera 1963).

13. Conyza bonariensis (L.) Cronquist., Bull. Torrey Bot. Club. 70:632. 1943. Fig. 4g-h Erigeron bonariensis L., Sp. Pl. 2: 863. 1753.

Ervas, 0,6-1,4 $\mathrm{m}$ alt., eretas, muito ramificadas; caule estriado, não fistuloso; Folhas membranáceas, oblanceoladas ou lanceoladas, 3,5-11,2 × 0,4-1,6 cm, concolores, ambas as faces pubescentes, venação hifófodroma, ápice agudo, margem inteira ou irregularmente denteada, base atenuada, sésseis. Capítulos heterógamos, disciformes, dispostos em panícula, pedunculados; receptáculo plano, glabro; invólucro campanulado, ca. $5 \times 6 \mathrm{~mm}$, brácteas involucrais 26-33, dispostas em 3 séries, reflexas na maturidade, lanceoladas, pubescentes, ápice agudo, margem inteira, hialina. Flores marginais pistiladas, 80-115; corola filiforme, branca, ca. $4 \mathrm{~mm}$ compr., pubescente na região apical, ápice 2-3 denteado. Flores do disco bissexuadas, 6-10; corola branca, ca. $4 \mathrm{~mm}$ compr., glabra, lobos pilosos. Cipsela obovóide, ca. $1 \mathrm{~mm}$ compr.; papilho 1-seriado, ca. 3,5 mm compr., cerdas sinples alvas.

Floresceu de novembro a fevereiro. Originária da América do Sul, disseminada como ruderal em todo mundo (Cabrera 1974). Material examinado: Viçosa, MP, Área em torno da sede, 24.I.2005, fl. e fr., S.C. Ferreira \& I. Rodrigues 43 (VIC); Margem da lagoa principal, 12.XI.2004, fl., S.C. Ferreira et al. 30 (VIC); 26.XI.2004, fl.e fr., S.C. Ferreira et al. 32 (VIC); 26.XI.2004, fl., S.C. Ferreira et al. 35 (VIC); Trilha principal, 17.XII.2004, fl., S.C. Ferreira \& E. Duarte 38 (VIC); 24.I.2005, fl., S.C. Ferreira \& I. Rodrigues 48 (VIC); 21.II.2005, fl. e fr., S.C. Ferreira \& I. Rodrigues 71.

14. Cosmos sulphureus Cav., Icon. 1(3): 56, pl. 79. 1791.

Fig. $4 \mathrm{i}$

Ervas anuais, ca. 1,8 m, eretas; caule levemente achatado, estriado, glabro. Folhas 
opostas, pinatissectas, membranáceas, 4,5-10,5 $\times 1,6-7,5 \mathrm{~cm}$, segmentos heteromorfos, ambas as faces glabras, ápice agudo, margem ciliada, pecíolo 0,6-2,2 cm compr. Capítulos heterógamos, radiados, em panículas, pedunculados, pedúnculos 7-19,5 cm compr.; receptáculo convexo, paleáceo, páleas lanceoladas; invólucro ca. 0,7 × 1,5 cm; brácteas involucrais lanceoladas, ápice agudo, externas pontuadas de glândulas, margem ciliada, internas glabras;. Flores do raio 8-9, neutras; corola amarela, tubo ca. $1,5 \mathrm{~mm}$ compr., glabro, limbo ca. 2,5 cm compr., glabro, ovado, 3-lobado. Flores do disco numerosas, corola alaranjada, ca. $8 \mathrm{~mm}$ compr., esparso pubescente, lobos ca. $2 \mathrm{~mm}$ compr., pilosos internamente; anteras vináceas. Cipsela enegrecidas, ca. 3-5 mm compr., pilosa; papilho 2-3 mm compr., com 2 aristas, tricomas retrosos.

Material examinado: Viçosa, MP: Entrada da Reserva, 14.IV.2005, f1., S.C. Ferreira \& L.C. P. Lima 99 (VIC).

Floresce de abril a maio.

15. Eclipta alba (L.) Hassk., Pl. Jav. Rar. 528. 1848. Fig. $4 \mathrm{j}$

Verbesina alba L., Sp. Pl. 2: 902. 1753.

Ervas, anuais ca. 60-80 m alt., eretas; caule anguloso, levemente achatado, estriado, fistuloso, estrigoso, tricomas adpressos. Folhas opostas, membranáceas, lanceoladas, 7,1-15,4 $\times 1,1-3 \mathrm{~cm}$, ambas as faces estrigosas, ápice agudo, margem crenada a serreada, base cuneada, amplexicaule, sésseis. Capítulos heterógamos, radiados, solitários, pedunculados, pedúnculo 1,5-4,5 cm compr.; receptáculo paleáceo, convexo, páleas lineares; invólucro campanulado ca. $4 \times 7 \mathrm{~mm}$, brácteas involucrais dispostas em 2 séries, elípticas a lanceoladas, estrigosas, ápice agudo a caudado. Flores do raio pistiladas, com corola branca, tubo ca. $2 \mathrm{~mm}$ compr., glabro, limbo ca. 1,5 mm, glabro, inteiro. Cipsela triqueta, ca. $2 \mathrm{~mm}$ compr., glabra. Flores do disco hermafroditas com corola branca, 2 mm compr., glabra, ápice 5-denteado; anteras enegrecidas, base obtusa; ramos do estilete com base triangular, pubescente no dorso. Cipsela ca. 1,5 mm compr., verrucosa, glabra; papilho ausente.

Material examinado: Viçosa, MP, Margem da lagoa principal, 26.XI.2004, fl., S.C. Ferreira et al. 34 (VIC); 24.I.2005, fl., S.C. Ferreira \& I. Rodrigues 49 (VIC).

Floresce de novembro a janeiro. Ocorre principalmente em regiões temperadas (Barroso 1959). Segundo Baker (1884), E. alba encontrase distribuída no Paraguai, Uruguai, Argentina e Brasil, ocorrendo na Amazônia, Pernambuco, Bahia, Minas Gerais e Rio de Janeiro.

16. Elephantopus mollis Kunth in H.B.K., Nov. Gen. Sp. Pl. 4:26. $1820 . \quad$ Fig. 4k-1

Ervas perenes, $25-80 \mathrm{~cm}$ de alt., eretas, raro decumbentes; ramos cilíndricos, estriados, fistulosos, os mais velhos castanhos, seríceos, tricomas adpressos. Folhas concentradas na região basal do caule, alternas, cartáceas a subcoriáceas, basais $6,1-15,5 \times 3-7 \mathrm{~cm}$, superiores $1,9-6 \times 1,5-2,8 \mathrm{~cm}$, discolores, face adaxialesparso estrigosa a serícea, face abaxial densoserícea, pontuada de glândulas, ápice agudo a obtuso mucronulado, margem crenada a denteada, base atenuada, amplexicaule, sésseis. Inflorescências corimbiformes; capítulos homógamos, discóides, agregados em capítulos cooflorescência, protegida por três brácteas foliáceas, ovadas a cordadas, seríceas; receptáculo convexo, glabro; invólucro cilíndrico, ca $7 \times 2,5 \mathrm{~mm}$; brácteas involucrais 8, dispostas em 4 séries, externas e internas lanceoladas, ápice acuminado, pubescente, pontuado de glândulas, margem inteira. Flores 4; corola branca, ca. 4,5 mm compr., glabra; anteras calcaradas; ramos do estilete com uma única área estigmática. Cipsela 2-3 mm compr., serícea; papilho 1-seriado, ca. $5 \mathrm{~mm}$ compr., escamiforme, 5 cerdas.

Material examinado: Viçosa, MP, Margem da lagoa menor, 11.III.2005, fl.e fr., S.C. Ferreira 80 (VIC); 11.III.2005, fl., S.C. Ferreira 81 (VIC); Margem da lagoa principal, 1.IV.2005, fl. e fr., S.C. Ferreira \& L.C.P. Lima 86 (VIC); Trilha dos Gigantes, 1.IV.2005, fl., S.C. Ferreira \& L.C.P. Lima 89 (VIC); Trilha do aceiro, 16.05.2005, fl., S.C. Ferreira \& I. Rodrigues 118 (VIC); Trilha no interior da mata, 25.I.2005, fr., 
S.C. Ferreira \& I. Rodrigues 54 (VIC); 1.IV.2005, fl. e fr., S.C. Ferreira \& L.C.P. Lima 91 (VIC); Trilha principal, 15.I.1990, fl., M. Thiengo 77(VIC);26.XI.2005, fl., S.C. Ferreira et al. 37 (VIC); 14.IV.2005, fr., S.C. Ferreira \& L.C. P. Lima 101 (VIC).

Floresce de janeiro a junho. Segundo Busey (1975) possui ocorrência pantropical, sendo, no Brasil, encontrada em todos os estados (Cabrera \& Klein 1980).

17. Emilia fosbergii Nicolson, Phytologia 32(1): 34. 1975.

Ervas anuais, $30-50 \mathrm{~m}$ alt.; caule cilíndrico, fistuloso, estriado, pubescente. Folhas alternas, membranáceas, oval-lanceoladas, 5,1-16,5×1,2$5,7 \mathrm{~cm}$, face adaxial glabra, face abaxial pubescente na região da nervura central, ápice acuminado, margem denteada, base amplexicaule, sésseis. Capítulos homógamos, discóides, organizados em cimas corimbiformes, pedúnculos $0,8-4,2 \mathrm{~cm}$ compr.; receptáculo plano, glabro; invólucro unisseriado cilíndrico ca. $1 \times 3 \mathrm{~cm}$, brácteas involucrais 12, conadas formando um gamófilo, lanceoladas, esparsamente pubescentes, ápice acuminado, margem hialina. Flores 65-70; corola vermelha, glabra, ca. $1 \mathrm{~cm}$ compr. Cipsela imatura ca. 3-4 cm compr., pubescente; papilho ca. $6 \mathrm{~mm}$ compr, alvo.

Material examinado: Viçosa, MP, Trilha principal, 13.X.1989, fl., M. Thiengo 07 (VIC); 22.X.2002, fl., A.D. Koehler et al. (VIC 29.518); 11.III.2005, fl., S.C. Ferreira 84 (VIC).

Floresce ao longo de todo o ano. De acordo com Pruski (1997) apresenta ampla distribuição.

18. Erechtites valerianifolia (Wolf) DC., Prodr. 6: 294. 1838.

Senecio valerianifolia Wolf, Icon. Bot. Exot. 59. 1827.

Ervas, 0,7-1,6malt:; caule cilíndrico, fistuloso, estriado, pubescente. Folhas irregularmente pinatissectas, $6,1-16,5 \times 2,4-7,8 \mathrm{~cm}$, segmentos lanceolados, ambas as faces glabras, esparsotomentosas na região da nervura central, ápice acuminado, margem denteada, sésseis. Capítulos heterógamos, disciformes, pedunculados, pedúnculo 1-2 cm compr. caliculado; receptáculo plano, glabro; invólucro unisseriado, ca. $10 \times 4$ $\mathrm{mm}$, brácteas involucrais 12 , lanceoladalineares, conadas formando um gamófilo, glabras, ápice acuminado, margem hialina. Flores marginais com corola lilás, ca. $8 \mathrm{~mm}$ compr., glabra, ápice papiloso. Flores do disco com corola lilás, ca. $1 \mathrm{~cm}$ compr., glabra, lobos papilosos. Cipsela ca. $2 \mathrm{~mm}$ compr., pilosa; papilho 0,8-1 cm compr., róseo.

Material examinado: Viçosa, MP, Margem da lagoa menor, 3.II.2005, fl., S.C. Ferreira \& L.C.P. Lima 58 (VIC); 3.II.2005, fl., S.C. Ferreira \& L.C.P. Lima 59 (VIC); 30.X.1989, fl., M. Thiengo 33 (VIC); Trilha principal, 24.I.2002, fl., S.C. Ferreira \& I. Rodrigues 46 (VIC); Trilha principal, 23.II.2002, fr., S.C. Ferreira et al. 75 (VIC).

Floresce de outubro a janeiro. Desde o México até a Argentina, Ásia tropical, Ilhas do Pacífico e norte da Austrália (Moraes 1997).

19. Erigeron maximus (D. Don) Otto ex DC., Prodr. 5:284. 1836.

Leptostelma maximum D. Don, Brit. Fl. Gard. 1:38. 1831

Ervas ca. 1 m alt., eretas, monóicas; caule estriado, fistuloso, pubescente. Folhas alternas, membranáceas, elípticas ou lanceoladas, 4,5$14,8 \times 1,1-3,9 \mathrm{~cm}$, levemente discolores, ambas as faces estrigosas, venação peninérvia, ápice agudo, margem denteado-apículada, base das folhas superiores aurículada, das folhas basais atenuada, sésseis. Capítulos heterógamos radiados, dispostos em panículas, pedunculados, pedúnculo 2,0-4,5 cm compr.; receptáculo plano, glabro; invólucro largamente campanulado, ca. $0,5 \times 1,3 \mathrm{~cm}$, brácteas involucrais dispostas em 3 séries lanceoladas a oblongas, pubescentes, ápice agudo, margem hialina. Flores do raio pistiladas, dispostas em duas séries, com lígula delgada, distintamente expandida; corola branca, tubo ca. $3 \mathrm{~mm}$ compr., pubescente, lígula ca. $1,3 \mathrm{~cm}$, glabra. Flores do disco, hermafroditas, disposta em várias séries, amarelas; corola ca. $5 \mathrm{~mm}$ compr., pubescente. Cipsela comprimida, ca. $1 \mathrm{~mm}$ compr., pubescente na região apical, 2-costada; papilho 2-seriado, ca. 4 mm compr., cerdas capilares, alvo.

Material examinado: Viçosa, MP, 3.IV.1984, fl., L.S. de Moura et al. 534 (VIC). 
Material adicional examinado: Viçosa, Fazenda do Tôte, 22.V.2000, fl., A.F. Carvalho 595 (VIC).

A espécie floresce em maio. Ocorre de Minas Gerais, na Zona da Mata, até o Rio Grande do Sul e Paraguai (Moraes 1997).

20. Fleischmannia remotifolia (DC.) R.M. King \& H. Rob., Phytologia 19(4):205.1970.

Fig. 4m-n

Eupatorium remotifolium DC., Prodr. 5: 165. 1836.

Ervas eretas ou escandentes, 0,6-1,5 m; ramos cilíndricos, fistulosos, lisos, pubescentes, pontuados de glândulas. Folhas opostas, membranáceas, ovadas, 3,7-6,9 ×1,8-3,7 cm, esparso-pubescentes em ambas as faces, face abaxial pontuada de glândulas ou não, trinérvia, ápice agudo a acuminado, margem serreada, base obtusa, pecíolo 1-5,1 cm compr., pubescente. Capítulos homógamos, discóides, dispostos em panículas de cimeiras corimbiformes, pedunculados; receptáculo plano, glabro; invólucro cilíndrico a campanulado, ca. $6 \times 4 \mathrm{~mm}$, brácteas involucrais 21-24, dispostas em 3 séries, desiguais em comprimento, externas fortemente menores, medianas e internas aproximadamente de tamanho igual, todas lanceoladas, esparsopubescentes, margem ciliada, ápice acuminado. Flores 23-24; corola alva, raro rósea, ca. $4 \mathrm{~mm}$ compr., glabra, lobos glabros; anteras com base obtusa; ramos do estilete levemente clavados, base não dilatada, glabra. Cipsela ca. 1,5 mm compr., esparso-pubescente, 5-costada; papilho ca. $3 \mathrm{~mm}$ compr., alvo, cerdas muito finas.

Material examinado: Viçosa, MP, Área ao redor da sede, 17.XII.2004, fl. e fr., S.C. Ferreira \& E. Duarte 42 (VIC); Trilha circuito das águas, 28.VII.2005, fl., S.C. Ferreira \& M. Godinho 150 (VIC); 9.IX.2005, fl. e fr., S.C. Ferreira et al. 176 (VIC); Trilha no interior da mata, 29.IX.2004, fl., S.C. Ferreira et al. 09 (VIC); 25.VIII.2005, fl. e fr., S.C. Ferreira \& D. Francino 169(VIC); 9.IX.2005, fl. e fr., S.C. Ferreira et al. 174 (VIC); Trilha principal, 22.10.2002, fl. e fr., P.B. de Souza et al. (VIC 29.526); 29.IX.2004, fl., S.C. Ferreira et al. 06 (VIC); 1.X.2005, fl., S.C. Ferreira \& M. Eiterer 13 (VIC).

Floresce de julho a dezembro. E. remotifolium é frequentemente confundida com Fleischmannia laxum Gardner, que apresenta brácteas involucrais internas com ápice obtuso, corola com tubo e limbo fracamente distintos, folhas com pecíolo curto e hábito mais robusto, enquanto que em $F$. remotifolium as brácteas involucrais internas apresentam ápice acuminado, corola com tubo e limbo distintos, folhas com pecíolo mais longo e o hábito é mais delicado. Distribui-se no Mato Grosso, Goiás, Espírito Santo, Rio de Janeiro, Minas Gerais e São Paulo (Barroso 1950; Esteves 2001).

21. Galinsoga parviflora Cav., Icon. 3(2): 4142, pl. 281. 1794.

Fig. 4o

Ervas anuais, 15-50 $\mathrm{m}$ alt., eretas; caule cilíndrico, fistuloso, estriado, pubescente. Folhas opostas, membranáceas, ovadas a elípticas, 2,5$5,6 \times 0,9-4,1 \mathrm{~cm}$, ambas as faces estrigosas, ápice agudo, margem serreada, base atenuada, pecíolo 0,5-4,4 cm. Capítulos heterógamos, radiados, dispostos em cimas corimbiformes axilares e terminais, pedunculados, pedúnculos 0,5-1,5 cm; receptáculo convexo, paleáceo, páleas lanceoladas, externas recobrindo a flor ligulada; invólucro campanulado, ca. 4x3 mm, brácteas involucrais dispostas em 2 séries, brácteas externas ovadas, pontuada de glândulas, ápice agudo, internas oblanceoladas, glabras, ápice agudo. Flores do raio pistiladas, com corola branca, tubo ca. $3 \mathrm{~mm}$ compr., pubescente, limbo ca. $2 \mathrm{~mm}$ compr., glabro, 3denteado; cipsela angular, comprimida dorsiventralamente ca. $2 \mathrm{~mm}$ compr., pubescente. Flores do disco hermafroditas, com corola amarela, 1,5 mm compr., glabra, ápice 5denteado; anteras com base curtamente sagitada; cipsela angulada, ca. 1,5 mm compr., pubescente; papilho paleáceo ca. $1 \mathrm{~mm}$ compr. Material examinado: Viçosa, MP, Margem da lagoa menor, 3.II.2005, fl., S.C. Ferreira \& L.C.P. Lima 61 (VIC); Trilha principal, 30.X.1989, fl., M. Thiengo 44 (VIC); Trilha principal, 24.I.2005, fl., S.C.Ferreira \& I. Rodrigues 51 (VIC); 14.II.2005, fl. e fr., S.C. Ferreira \& D. Francino 63 (VIC).

Floresce ao longo de todo o ano. Originária do Peru, frequente nas Américas e em muitos países da Europa, como planta ruderal (Barroso 1959). 
22. Gamochaeta americana (Mill.) Wedd., Chlor. And. 1:151. 1856.

Gnaphalium americanum Mill., Gard. Dict. 8:17. 1768.

Ervas 20-50 cm alt.; caule achatado, costado, albo-seríceo. Folhas alternas, inteiras, sésseis, tomentosas, membranáceas, oblanceoladas, 3,5-10,7 $\times 0,5-1,6 \mathrm{~cm}$, discolores, face adaxial glabra, face abaxial albo-tomentosa, ápice obtuso, margem ondulada, com base ondulada a denteada, atenuada, sésseis. Capítulos heterógamos, disciformes, dispostos em cimas espiciformes, terminais, curto-pedunculados; receptáculo plano, glabro; invólucro hemisférico, ca. $3 \times 2 \mathrm{~mm}$, brácteas involucrais dispostas em duas séries, externas ovadas, internas lanceoladas. Flores marginais ca. 90, pistiladas; corola filiforme, ca. $3 \mathrm{~mm}$ compr., creme, glabra, ápice papiloso. Flores centrais 3-4, hermafroditas, corola creme, glabra, lobos papilosos. Cipsela oblonga, 5-8 mm compr., pontuada de glândulas; papilho 2-3 mm compr., alvo ou avermelhado, cerdas concrescidas na base.

Material examinado: Viçosa, MP, Margem da lagoa principal, 12.XI.2004, fl. e fr., S.C. Ferreira et al. 33 (VIC); 11.III.2005, fl. e fr., S.C. Ferreira 82 (VIC).

Floresce ao longo de todo ano. Amplamente distribuídas nos trópicos (Hind 1995).

23. Grazielia intermedia (DC.) R.M. King \& H. Rob., Phytologia 23(3): 306. 1972.

Fig. $4 p-q$

Eupatorium intermedium DC., Prodr. 5:146. 1836.

Subarbustos eretos, raro apoiantes, ca. 2,5 $\mathrm{m}$; ramos cilíndricos, lisos, tomentosoferrugíneos, pontuados de glândulas. Folhas opostas, cartáceas, lanceoladas, 4,5-14,5 × 0,9-2,5 cm, discolores, face adaxial esparsoestrigosa, face abaxial tomentosa, peninérvia, ápice agudo, margem serreada, base cuneada, pecíolo 0,3-1 cm compr., tomentoso-ferrugíneo, pontuado de glândulas. Capítulos homógamos, discóides, dispostos em cimas corimbiformes, subsésseis; levemente convexos, glabros; invólucro subcampanulado, ca. $5 \times 2 \mathrm{~mm}$, brácteas involucrais 10-12, dispostas em 3 séries desiguais em comprimento, externas gradualmente menores, ovadas, internas oblongas, ápice obtuso, tomentoso. Flores 5; corola alva a lilás, ca. 3,5 mm compr., lobos glabros; anteras com base obtusa; ramos do estilete levemente clavados, base não dilatada, glabra. Cipsela ca. $2 \mathrm{~mm}$ compr., glabra, 5costada; papilho ca. $3 \mathrm{~mm}$ compr., alvo.

Material examinado: Viçosa, MP, Trilha principal, 11.III.2005, fl., S.C. Ferreira 85 (VIC); 1.IV.2005, fl. e fr., S.C. Ferreira 90 (VIC); 6.IV.2005, fl., S.C. Ferreira 96 (VIC).

Floresce em março e abril, sendo suas flores visitadas por abelhas e vespas. A espécie é semelhante à Grazielia serrata (Spreng.) R. King \& H. Rob. e G. alpestre (Gardner) R.L. Esteves, podendo ser diferenciada de ambas pela lâmina foliar, que na primeira é linear e na segunda a face adaxial é glabra a curtamente pubescente, enquanto em $G$. intermedia a lâmina apresenta formato lanceolado e face abaxial tomentosoferrugínea Distribui-se nas regiões sul e sudeste do Brasil, de Minas Gerais ao Rio Grande do Sul (Esteves 2001). G. intermedia pode ser encontrada em vegetação de cerrado, campo rupestre, restinga, borda de floresta e nos campos do sul do Brasil (Esteves 2001).

24. Heterocondylus R.M. King \& H. Rob., Phytologia 24(5):389.1972.

Arbustos ertos ou escandentes. Folhas inteiras, opostas, sésseis ou pecioladas. Capítulos homógamos, discóides, dispostos em cimas corimbiformes, raro isolados; receptáculo plano, glabro; invólucro campanulado a hemisférico; brácteas involucrais persistentes, dispostas em 3-5 séries. Flores hermafroditas, 20-100, corola infundibuliforme com limbo e tubo fracamente diferenciados, lobos triangulares, mais compridos que largos, lisos em ambas as faces, com ou sem tricomas glandulares na face externa; ramos do estilete lineares ou subclaviformes, lisos ou curtamente papilosos, base dilatada, glabra ou pilosa. Cipselas prismáticas, (4)-5-costadas, tricomas glandulares capitados e tricomas geminados; papilho de cerdas barbeladas, persistentes. 
Chave para identificação das espécies de Heterocondylus da MP

1. Arbustos eretos; ramos lisos, pontuados de glândulas; capítulo com 21-29 flores

1. H. vauthierianus

1'. Arbustos escandentes; ramos estriados, sem pontuações glandulares; capítulo com 45-53 flores

2. H. vitalbae

24.1 Heterocondylus vauthierianus (DC.) R.M. King \& H. Rob. Phytologia 24: 391. 1972.

Fig. 5a-b

Eupatorium vauthierianum DC., Prodr. 5: 159.1836.

Arbustos eretos, 1,5-2 m; ramos cilíndricos, lisos, pubescescentes, densamente pontuados de glândulas. Folhas opostas, membranáceas a cartáceas, ovadas a ovado-lanceoladas, 7,5$13,2 \times 2,3-5,8 \mathrm{~cm}$, face adaxial estrigosa, face abaxial esparso-pilosa, ambas as faces pontuadas de glândulas, trinérvia, ápice acuminado, margem serreada, base obtusa, decorrente na região distal do pecíolo, pecíolo 1,5-3,5 cm compr., pubescente, pontuado de glândulas. Capítulos dispostos em panículas de cimeiras corimbiformes, pedunculados; invólucro campanulado, 1,1-1,3 × 0,8-1 cm, brácteas involucrais 25-27, dispostas em 3 séries, desiguais em comprimento, externas gradualmente menores, oblongas, internas lanceoladas, pubescentes, pontuadas de glândulas. Flores 21-29; corola lilás, ca. 1 cm compr., glabra, lobos glabros; anteras com base obtusa; ramos do estilete lineares, base pilosa. Cipsela 4-5 mm compr., esparsamente pubescente, pontuada de glândulas, 5-costada; papilho ca. $8 \mathrm{~mm}$ compr., alvo.

Material examinado: Viçosa, MP, Trilha principal, 27.IX.1995, fl., R.M. Carvalho-Okano (VIC 15.071); 29.IX.2005, fl., S.C. Ferreira et al. 05 (VIC); 20.X.2005, fr., S.C. Ferreira et al. $18 b$ (VIC); 20.X.2005, fl., S.C. Ferreira \& D. Francino 143 (VIC); 5.VIII.2005, fl., S.C. Ferreira \& E.C. Cabrini 158 (VIC).

Floresce de julho a outubro. No Brasil, é encontrada em Mato Grosso, Goiás, Mato Grosso do Sul, Minas Gerais, Espírito Santo, Rio de Janeiro, São Paulo, Paraná e Santa Catarina (Cabrera \& Klein 1989; Esteves 2001).
24.2 Heterocondylus vitalbae (DC.) R.M. King \& H. Rob., Phytologia, 24(5):391.1972.

Fig. $5 c-d$

Eupatorium vitalbae DC., Prodr. 5:163. 1831.

Arbustos escandentes; ramos cilíndricos, estriados, pubescentes. Folhas opostas, cartáceas, ovadas a ovado-lanceoladas, 3,7-11,5 × 1,8$5,1 \mathrm{~cm}$, levemente discolores, face adaxial glabra, face abaxial esparso-pubescente a glabra, trinérvia, ápice agudo a acuminado, margem serreada, base obtusa, pecíolo 6-12 mm compr., pubescente. Capítulos dispostos em panículas de cimeiras corimbiformes, pedunculados; invólucro campanulado, 8-10× 5-7 mm, brácteas involucrais 22-24, dispostas em 3 séries, desiguais em comprimento, externas gradualmente menores, ovadas, pubescentes, vináceas, internas lanceoladas, glabras, verdes, ápice acuminado. Flores 4553; corola lilás, ca. $6 \mathrm{~mm}$ compr., glabra, lobos glabros; anteras com base obtusa; ramos do estilete lineares, base glabra. Cipsela ca. $7 \mathrm{~mm}$ compr., pubescente, pontuada de glândulas, 5costada; papilho ca. $7 \mathrm{~mm}$ compr., alvo.

Material examinado: Viçosa, MP, borda de mata, 20.IX.2002, fl., P.B. de Souza (VIC 29.527); Trilha principal, 1.X.2004, fl., S.C. Ferreira \& M. Eiterer 15 (VIC); 17.XII.2004, fr., S.C. Ferreira \& E. Duarte 40 (VIC).

Floresce de setembro a dezembro. No Brasil, a espécie ocorre em Goiás, Minas Gerais, Rio de Janeiro e São Paulo (Esteves 2001).

25. Hypochaeris brasiliensis (Less.) Benth. \& Hook. f. ex Griseb, Abh. Konigl. Ges. Wiss. Gottingen. 24: 217. 1879.

Porcellites brasiliensis Less., Linnaea 6(1): 103-104. 1831.

Ervas perenes, latescentes, ca. $50 \mathrm{~cm}$ alt.; caule cilíndrico, fistuloso, anguloso, hirsuto, 
tricomas ramificados, multicelulares. Folhas basais alternas, lanceoladas, 7,5-12,5 × 3,8$5,5 \mathrm{~cm}$, face adaxial glabrescente, face abaxial pubescente, ápice agudo, margem profundamente lobada, base atenuada ou amplexicaule, sésseis; folhas superiores lineares, 3-6×0,2$0,4 \mathrm{~cm}$, base amplexicaule. Inflorescências em panículas; pedúnculo até $10,5 \mathrm{~cm}$ compr.; receptáculo plano, paleáceo, páleas com ápice aristado; invólucro campanulado, ca. 1,3 ×0,6 $\mathrm{cm}$; brácteas involucrais dispostas em 4-5 séries, lanceoladas, glabras, ápice agudo ou obtuso, margem hialina; flores liguladas, corola amarela, tubo ca. $5 \mathrm{~mm}$ compr., glabro, limbo ca. 2 mm compr. glabro. Cipsela 1,1 cm compr., incluindo rostro ca. $6 \mathrm{~mm}$, glabra; papilho ca. $6 \mathrm{~mm}$ compr., plumoso, alvo.

Material examinado: Viçosa, MP, Trilha principal, 12.XI.2004, fl. e fr., S.C. Ferreira et al. 29 (VIC); 25.XI.2002, fl., A.D. Koehler et al. (VIC 29.519).

Floresce de outubro a dezembro. Ocorre na região Sul do Brasil, Paraguai, Norte e Centro da Argentina (Cabrera 1974). Baker
(1882), citou a espécie para os estados de Santa Catarina, Rio de Janeiro e Minas Gerais.

26. Mikania Will., Sp. P1., ed.4. 3(3): 1742.1803.

Ervas, subarbustos, arbustos ou lianas; ramos cilíndricos ou angulosos. Folhas simples ou compostas, opostas, raro verticiladas, sésseis ou pecioladas. Capítulos homógamos, discóides, dispostos em cimas paniculiformes, tirsiformes, racemiformes, espiciformes ou corimbiformes, geralmente subtendidos imediatamente por bráctea subinvolucral; brácteas involucrais 4, livres, persistentes; receptáculo plano, epaleáceo. Flores hermafroditas, 4; corola tubulosa, tubo estreito, limbo geralmente campanulado, lobos triangulares, lanceolados, ovais ou oblongos; anteras com apêndice oval a oblongo; ramos do estilete lineares, com ápice clavado, base não dilatada. Cipsela geralmente 5-costadas; papilho cerdoso, cerdas persistentes, aproximadamente do comprimento da corola.

\section{Chave para identificação das espécies de Mikania da MP}

1. Capítulos sésseis, densamente aglomerados

3. M. glomerata

1'. Capítulos pedunculados, não densamente aglomerados.

2. Ramos hexagonais

2. M. cordifolia

2'. Ramos cilíndricos ou achatados.

3. Ramos fistulosos, glabros.

4. Face adaxial da lâmina foliar pubescente, face abaxial velutina, 5-nérvia, margem serreada; cipsela sem pontuações glandulares 4. M. hemisphaerica

4'. Ambas as faces da lâmina foliar glabras ou glabrescentes, 3-nérvia, margem foliar inteira; cipsela pontuada de glândulas

5. Lâmina foliar com nervação 3-plinérvia (3-nervadas distintamente acima da base), base cuneada.

6. M. lindbergii

5'. Lâmina foliar com nervação 3-nérvia (3-nervada desde praticamente a base), base obtusa

8. M. trinervis

3'. Ramos não fistulosos, pilosos.

6. Ramos achatados, folhas hastadas, base hastada; cipsela pontuada de glândulas 7. M. salviefolia

6'. Ramos cilíndricos, folhas ovadas, base cordada ou truncada; cipsela sem pontuações glandulares.

7. Ramos e pecíolos hirsutos, brácteas involucrais elipticas, de ápice acuminado; corola glabra 5. M. hirsutissima

7'. Ramos e pecíolos seríceo-ferrugíneos, brácteas involucrais oblongas, de ápice obtuso; corola esparso-pilosa

1. M. argyreae 


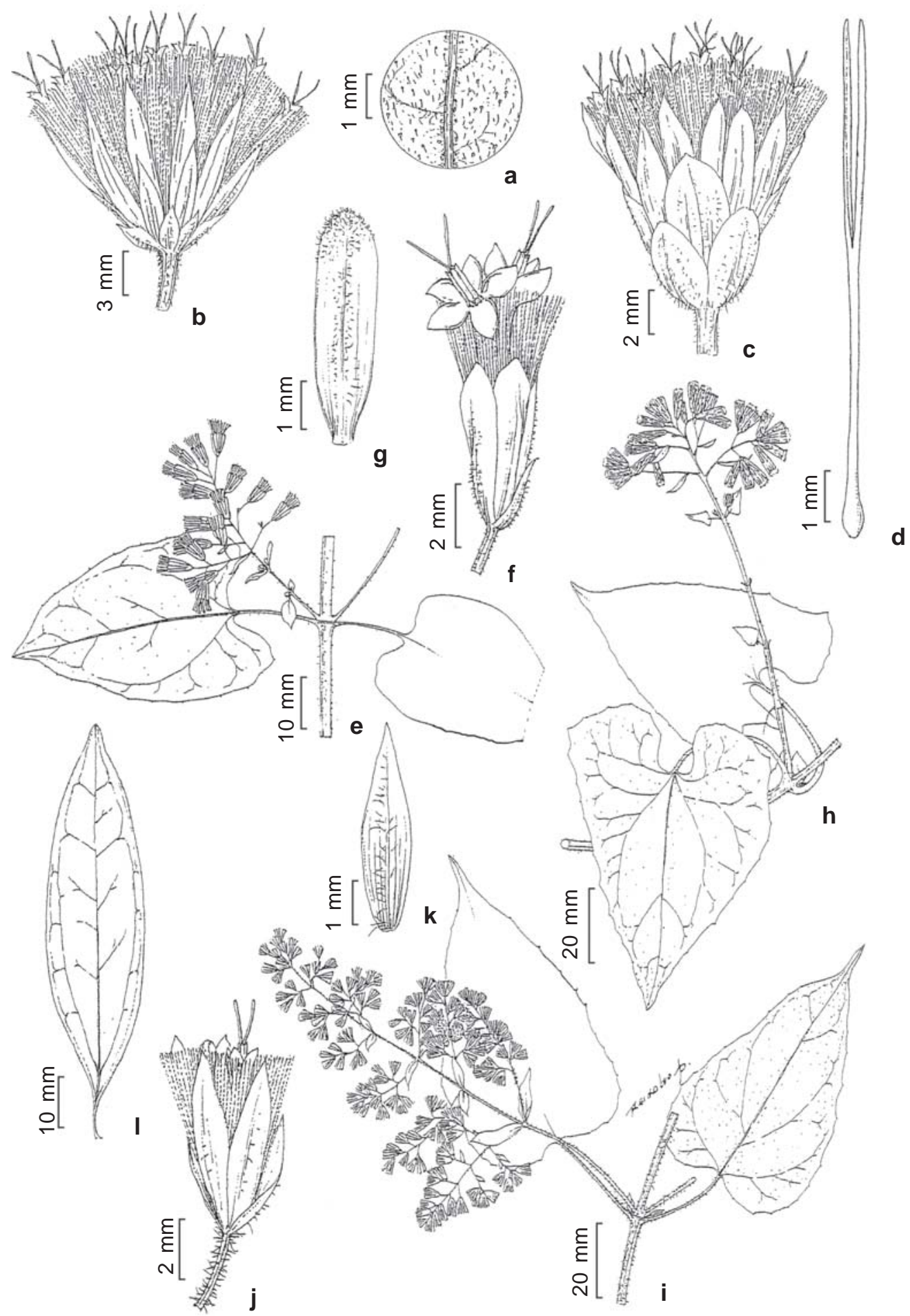

Figura 5 - a-b. Heterocondylus vauthierianus - a. indumento; b. capítulo. c-d. Heterocondylus vitalbae - c. capítulo; d. estilete. e-g. Mikania argyreae - e. ramo com capítulo; f. capítulo; g. bráctea. h. Mikania cordifolia - h. ramo com capítulo. i-k. Mikania hirsutissima - i. ramo com capítulo; j. capítulo; k. bráctea. 1. Mikania lindbergii - 1. folha.

Figure 5 - a-b. Heterocondylus vauthierianus - a. indument; b. head. c-d. Heterocondylus vitalbae - c. head; d. style. e-g. Mikania argyreae - e. branch with head; f. head; g. bract. h. Mikania cordifolia - h. branch with head. i-k. Mikania hirsutissima - i. branch with head; j. head; k. bracts. 1. Mikania lindbergii - 1. leaf. 
26.1. Mikania argyreae DC., Prodr., 5:193.1836.

Fig. 5e-g

Trepadeiras, ramos cilíndricos, não fistulosos, estriados, seríceo-ferrugíneos; internós 4-12,7 cm compr. Folhas inteiras, membranáceas, ovais, 2,5-11,9×1,2-6,7 cm, face adaxial estrigoso-ferrugínea, face abaxial seríceo-ferrugínea, 5-nérvia, ápice acuminado, margem inteira, base cordada a truncada, pecíolo 0,7-4,6 cm, seríceo-ferrugíneo. Capítulos dispostos em cimas paniculiformes, pedunculados, pedúnculo 1-1,2 cm compr.; brácteas subinvolucrais ovadas, ca. $2 \times 0,5 \mathrm{~mm}$ compr., velutinas, ápice agudo; brácteas involucrais oblongas, ca. $5 \times$ 1,5 mm, glabras, ápice obtuso, viloso. Corola branca a creme, tubo ca. $3 \mathrm{~mm}$ compr., esparso-pilosa, limbo 1,5 mm compr., lobos ca. $1 \mathrm{~mm}$ compr., triangulares, inflexos. Cipsela ca. $3 \mathrm{~mm}$, glabrescente; papilho 4-5 mm compr., alvo a amarelado.

Material examinado: Viçosa, MP, Trilha principal, 3.IX.2003, fl., M. Eiterer \& Guslan (VIC 28.819); 16.XI.2004, fl., M. Eiterer \& Guslan (VIC 29.070); 16.XI.2004, fl., M. Eiterer \& Guslan (VIC 29.072); 9.IX.2003, fl., M. F. Vieira 715 (VIC).

Floresceu de setembro a novembro, tendo como visitantes florais Apis melifera. Distribuíse no Brasil em Minas Gerais, Rio de Janeiro, São Paulo e Paraná (Barroso 1958). A espécie é encontrada com frequência na MP. $M$. argyreae é comumente confundida em herbário com $M$. hirsutissima. No entanto, $M$. argyreae apresenta ramos e pecíolos seríceoferrugíneos e brácteas involucrais oblongas de ápice obtuso, enquanto que em $M$. hirsutissima os ramos e pecíolos são hirsutos e as brácteas involucrais são lanceoladas de ápice acuminado.

26.2. Mikania cordifolia (L.f) Willd., Spec. Plant. 3:1804.

Fig. $5 \mathrm{~h}$

Cacalia cordifolia L.f., Suppl. Pl. 351352. 1781.

Trepadeiras, ramos hexagonais, fistulosos, lisos, pubescentes; internós 6,5-23,5 cm compr. Folhas inteiras, membranáceas a cartáceas, hastadas, 2,4-14,5 × 1,5-9,8 cm, ambas as faces estrigosas, face abaxial pontuada de glândulas, 5-nérvia, ápice agudo, margem inteira a irregularmente curto-denteada, base cordada, pecíolo 1,2-8 cm, seríceo, estriado. Capítulos dispostos em cimas paniculiformes, pedunculados, pedúnculos $0,6-1,1 \mathrm{~cm}$ compr.; brácteas subinvolucrais lanceoladas, ca. $6 \times 1,5 \mathrm{~mm}$, esparsamente velutinas, ápice acuminado; brácteas involucrais lanceoladas, $8 \times 2 \mathrm{~mm}$, glabras, ápice acuminado pubescente. Corola branca a esverdeada, tubo ca. $3 \mathrm{~mm}$, pontuado de glâdulas, lobos ca. 2 mm compr., pontuados de glândulas, triangulares. Cipsela $3 \mathrm{~mm}$, glabra; papilho ca. $5 \mathrm{~mm}$, alvo.

Material examinado: Viçosa, MP, Brejo, 3.IX.2003, fl., M. Eiterer \& Giuslan (VIC 28.822); Lagoa, 5.IX.1989, fl., M. Thiengo 102 (VIC); Margem da lagoa principal, 3.IX.2003, fl., M. Eiterer \& Giuslan (VIC 28.820); 22.VII.2005, fl., S.C. Ferreira \& D. Francino 138 (VIC); 22.VII.2005, fl., S.C. Ferreira \& D. Francino 139 (VIC); 25.VIII.2005, fl., S.C. Ferreira \& D. Francino 163 (VIC); Sede, 25.VIII.2005, fl., S.C. Ferreira \& D. Francino 167 (VIC); Trilha circuito das caminhadas, 28.VII.2005, fl., S.C. Ferreira \& M. Godinho 151 (VIC); VIII.2005, fl., S.C. Ferreira 154 (VIC); Trilha dos Gigantes, 14.VI.2005, fl., S.C. Ferreira et al. 132 (VIC); Trilha principal, 16.XI.2004, fl. e fr., M. Eiterer (VIC 29.069).

Floresce de junho a novembro. M. cordifolia é frequentemente confundida com $M$. micrantha Kunth, mas distingue-se principalmente pelo ramo hexagonal, que em $M$. micrantha é cilíndrico e pelo invólucro que apresenta quase o dobro do tamanho do invólucro encontrado em $M$. micrantha. A espécie encontra-se amplamente distribuída, sendo encontrada nos Estados Unidos, México, América Central, Antilhas e América do Sul (King \& Robinson 1987). Segundo Holmes (1995), apresenta a distribuição natural mais ampla entre as espécies de Mikania.

26.3. Mikania glomerata Spreng., Syst. Veg. 3:421. 1826.

Trepadeiras, ramos cilíndricos, fistulosos, estriados, glabros, internós 4,5-12 cm. Folhas inteiras, coriáceas, ovadas a triangulares, 4,7$13,1 \times 3,6-17,5 \mathrm{~cm}$, ambas as faces glabras, pontuadas de tricomas glandulares, ápice acuminado, margem ondulada, base cordada a truncada, pecíolo 1,7-9,8 cm, glabrescente 
com tricomas glandulares esparsos. Capítulos dispostos em panículas glomerosas, sésseis, densamente aglomerados; brácteas subinvolucrais lanceoladas, $1-2 \times 0,5 \mathrm{~mm}$, glabras, margem ciliada, ápice agudo; brácteas involucrais oblongas, $4 \times 1 \mathrm{~mm}$, glabras, ápice obtuso, curto apiculado, ciliado. Corola esverdeada a branca, tubo ca. 1,5 mm compr., glabro, limbo ca. 1,5 mm, glabro, lobos triangulares, curtamente ciliados, inflexos. Cipsela ca. 2,5 mm compr., esparsamente pubescente; papilho 4-4,5 mm compr., creme. Material examinado: Viçosa, MP, 20.IX.2002, fl., P.B. de Souza (VIC 29.530); Cabana, 23.X.1992, fr., M.F. Vieira 722 (VIC); Trilha no interior da mata, 27.IX.1995, fl., R.M. Carvalho-Okano (VIC 15.070); 3.IX.2003, fl., M. Eiterer \& Giuslan (VIC 28.817); Trilha principal, 12.IX.2001, fl., F.C.P. Garcia \& I.M. Corrêa 867 (VIC); 29.IX.2004, fr., S.C. Ferreira et al. 02 (VIC); 28.VII.2005, fl., S.C. Ferreira \& M. Godinho 148 (VIC); 15.VIII.2005, fl., S.C. Ferreira et al. 161 (VIC).

Floresce de julho a outubro. M. glomerata pode ser confundida, em herbário, com $M$. laevigata Sch. Bip. que apresenta folhas levemente lobadas, enquanto $M$. glomerata sempre apresenta folhas fortemente lobadas. Ocorre no Brasil, Paraguai e Nordeste da Argentina (Barroso 1958). No Brasil encontra-se distribuída na região sudeste e no estado da Bahia (Moraes 1997).

26.4. Mikania hemisphaerica Schultz-Bid in Mart., Fl. Bras. 6(2):254. 1876.

Trepadeiras, ramos cilíndricos, fistulosos, estriados, glabros, internós 6,5-15 cm compr. Folhas inteiras, membranáceas, ovadas, 3,3$10,2 \times 2-7 \mathrm{~cm}$, face adaxial esparso-puberulenta, face abaxial velutina, 5-nérvia, ápice acuminado, margem serreada, base cordada, pecíolo 1,54,5 cm compr., seríceo, estriado. Capítulos dispostos em panículas de cimeiras, pedunculados, pedúnculos 1,0-1,3 cm compr.; brácteas subinvolucrais lanceoladas, ca. $8 \times 2 \mathrm{~mm}$, glabras, ápice acuminado; brácteas involucrais lanceoladas 1-1,1×0,2-0,3 cm, glabras, ápice acuminado. Corola branca, tubo ca. $5 \mathrm{~mm}$ compr., glabro, limbo ca. $2 \mathrm{~mm}$ compr., glabro, lobos tringulares, ápice puberulento, inflexos. Cipsela 5-6 mm compr., esparso-velutina; papilho ca. $7 \mathrm{~mm}$ compr., rosado.
Material examinado: Viçosa, MP, estrada em direção a torre de madeira, 17.VI.1983, L.S. Moura et al. 476 (VIC).

Floresce em junho. Distribui-se no Brasil e na Argentina (King \& Robinson 1987). No Brasil, a espécie pode ser encontrada na Região Sudeste e no Pará (Barroso 1958).

26.5. Mikania hirsutissima DC., Prodr. 5:200.1836.

Fig. 5i-k

Trepadeiras, ramos cilíndricos, não fistulosos, estriados, hirsutos, tricomas amarelados, internós 8,2-23,5 cm compr. Folhas inteiras, cartáceas, ovadas, 4,5-20 × 3-12,2 cm, face adaxial estrigosa, face abaxial velutina, 5-plinérvia, ápice acuminado a curtamente caudado, margem inteira ou irregularmente denteada, base cordada, pecíolo 1,5-11,5 cm compr., hirsutos. Capítulos em panículas de cimeiras, pedunculados, pedúnculo 0,8-1,2 cm compr.; brácteas subinvolucrais ovadas a elípticas, ca. $4 \times 2 \mathrm{~mm}$, glabras, ápice acuminado a obtuso; brácteas involucrais lanceoladas ca. $6 \times 1,5 \mathrm{~mm}$ glabras, ápice acuminado com tricomas esparsos. Corola branca a creme, tubo ca. $3 \mathrm{~mm}$ compr., glabro, limbo ca. $2 \mathrm{~mm}$ compr. glabro, lobos triangulares, inflexos. Cipsela ca. $2 \mathrm{~mm}$, glabra; papilho ca. $3 \mathrm{~mm}$ compr. alvo.

Material examinado: Viçosa, MP, 20.IX.2002, fl., P.B. de Souza et al. (VIC 29.528); Margem da lagoa menor, 16.X.1998, fl. e fr., G. Pedralli et al. (VIC 23350); Margem da lagoa principal, 22.XII.2005, fl., S.C. Ferreira \& D. Francino 140 (VIC); 28.XII.2005, fl., S.C. Ferreira \& M. Godinho 144 (VIC); Trilha principal, 3.IX.2003, fl., M. Eiterer \& Giuslan (VIC 28818); 16.XI.2004, fl., M. Eiterer \& Giuslan (VIC 29.071); 9.IX.1992, fl., M.F. Vieira 716 (VIC); 29.IX.2004, fr., S.C. Ferreira 01 (VIC); 28.VII.2005; fl., S.C. Ferreira \& M. Godinho 149 (VIC).

Floresce de julho a outubro. Ocorre no Brasil e Argentina (King \& Robinson 1987). No Brasil a espécie encontra-se distribuída na Bahia, Minas Gerais, Rio de Janeiro, São Paulo, Paraná e Rio Grande do Sul (Barroso 1958).

26.6. Mikania lindbergii Baker in Mart., Fl. Bras. 6 (2):223. 1876. Fig. 51

Trepadeiras, ramos cilíndricos, fistulosos, estriados, glabros, internós 2,6-7,8 cm compr. 
Folhas inteiras, coriáceas, lanceoladas a elípticas, 4,5-11,5×1,4-3,8 cm compr., ambas as faces adaxial glabras, face abaxial com ou sem tricomas glandulares, 3-plinérvia, ápice acuminado, margem inteira, base cuneada, pecíolo 0,7-1,6 cm compr., glabro. Capítulos dispostos em panículas de cimeiras, pedunculados, pedúnculo $0,6-1,0 \mathrm{~cm}$ compr.; brácteas subinvolucrais lanceoladas a elípticas, ca. 2,5×1 mm, glabras, margem ciliada, ápice obtuso; brácteas involucrais oblongas a lanceoladas com base dilatada, ca. $4 \times 1 \mathrm{~mm}$, glabras, ápice acuminado, ciliado. Corola branca, tubo ca. $1,5 \mathrm{~mm}$, glabro, limbo ca. 1 $\mathrm{mm}$, glabro, lobos triangulares, glabros inflexos. Cipsela ca. 1,5 mm, pubescente, pontuada de glândulas; papilho ca. $2,5 \mathrm{~mm}$, alvo a rosado. Material examinado: Viçosa, MP, 26.VI.1999, fl., A.F. Carvalho 627 (VIC).

Floresce em junho. M. lindbergii é muito próxima de $M$. trinervis Hook \& Arn., podendo ser diferenciada principalmente por $M$. lindbergii apresentar lâmina foliar com nervação triplinérvia e base foliar cuneada, enquanto que em $M$. trinervis possui venação trinérvia e base foliar obtusa. No Brasil, ocorre da Bahia até Santa Catarina (Cabrera \& Klein 1989).

26.7. Mikania salviaefolia Gardn., London J. Bot. 5:487. 1846. Fig. 6a-b

Trepadeiras, ramos achatados, não fistulosos, estriados, pubescentes, pontuado de tricomas glandulares, internós 5,5-18 cm compr. Folhas inteiras, hastadas, membranáceas a cartáceas, 3,8-9,2 × 1,8-5,5 cm, face adaxial esparso-pubescente, glandular, face abaxial denso tomentoso-glandular, 3-nérvia, ápice agudo, margem inteira a irregularmente curtodenteada, base hastada, pecíolo $0,8-3,7 \mathrm{~cm}$ compr., esparso-tomentoso glanduloso. Capítulos dispostos em panículas de cimeiras, pedunculados pedúnculo $0,8-1,2 \mathrm{~cm}$ compr.; brácteas subinvolucrais oblongo-lanceoladas, ca. $1,5 \times 0,5 \mathrm{~mm}$, pubescentes, margem ciliada, ápice acuminado; brácteas involucrais oblongas, $7 \times 1,5 \mathrm{~mm}$, glabras, ápice obtuso, seríceo. Corola creme, tubo ca. $3 \mathrm{~mm}$, pontuada de tricomas glandulares, limbo ca. $1,5 \mathrm{~mm}$, pubescente, pontuado de tricomas glandulares, lobos triangulares, inflexos. Cipsela ca. $2 \mathrm{~mm}$ compr., glandulosa; papilho ca. 4 mm compr., róseo.

Material examinado: Viçosa, MP, Margem da lagoa principal, 5.VIII.2005, fl., S.C. Ferreira \& E. Cabrini 153 (VIC); 15.VIII.2005, fl., S.C. Ferreira 160 (VIC); 9.IX.2005, fl. e fr., S.C. Ferreira et al. 173 (VIC).

Floresce em agosto e setembro. No Brasil, a espécie encontra-se distribuída nos estados de Goiás, Minas Gerais e Rio de Janeiro (Barroso 1958).

26.8. Mikania trinervis Hook. \& Arn., Companion Bot. Mag. 1:244. 1836. Fig. 6c

Trepadeiras, ramos cilíndricos, fistulosos, estriados, glabros, internós 5,5-20 cm compr. Folhas inteiras, cartáceas, ovadas a elípticas, 4-10,2 $\times 2,3-6,5 \mathrm{~cm}$, face adaxial glabra, face abaxial glabrescente, com poucos tricomas esparsos na região da nervura central, 3-nérvia, ápice agudo a acuminado, margem inteira, base obtusa, pecíolo 0,8-2(3) cm compr., glabro, pontuado de glândulas. Capítulos dispostos em panículas, pedunculados, pedúnculo 1,5-2,0 cm compr.; brácteas subinvolucrais oblongas, 2 2,5 × 0,5 mm, esparso-vilosas, ápice obtuso; brácteas oblongas, ca. $5 \times 1 \mathrm{~mm}$, esparsovilosas, ápice obtuso. Corola branca, tubo 11,5 mm, glabro, limbo $3 \mathrm{~mm}$ compr., glabro, lobos triangulares, inflexos. Cipsela ca. $4 \mathrm{~mm}$ compr., glandulosa; papilho ca. $4 \mathrm{~mm}$, creme. Material examinado: Viçosa, MP, Trilha no interior da mata, 3.IX.2005, fl. e fr., M. Eiterer \& Giuslan (VIC 28.821); 25.VIII.2005, fl., S.C. Ferreira \& D. Francino 168(VIC); 9.IX.2005, fl. e fr., S.C. Ferreira et al. 171 (VIC).

Floresce de agosto a setembro. No Brasil, a espécie ocorre de Minas Gerais a Santa Catarina (Barroso 1958). Segundo Cabrera \& Klein (1989), a distribuição da espécie estendese do Rio de Janeiro até Rio Grande do Sul.

27. Mutisia speciosa Ait., Bot. Mag. 54: 2705. 1827.

Fig. 6d

Trepadeiras com até $5 \mathrm{~m}$; caule quadrangular, glabrescente, internós 6-12 cm. Folhas alternas, pinaticompostas, terminadas em gavinhas trífidas, raque $9-11,5 \mathrm{~cm}$, esparsamente tomentosa; 

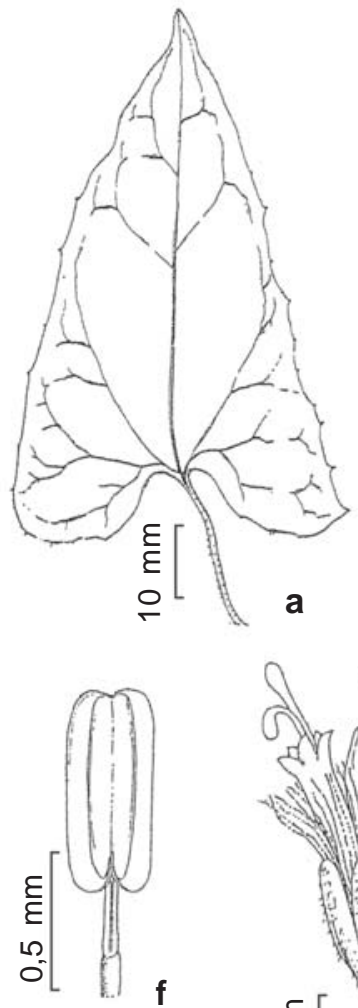
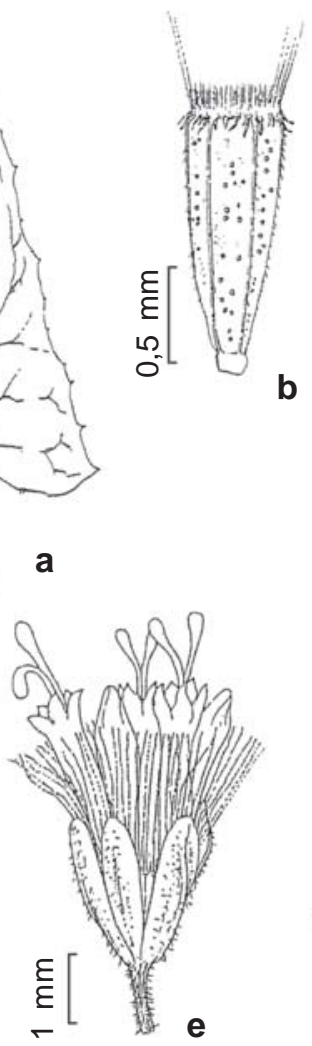

b
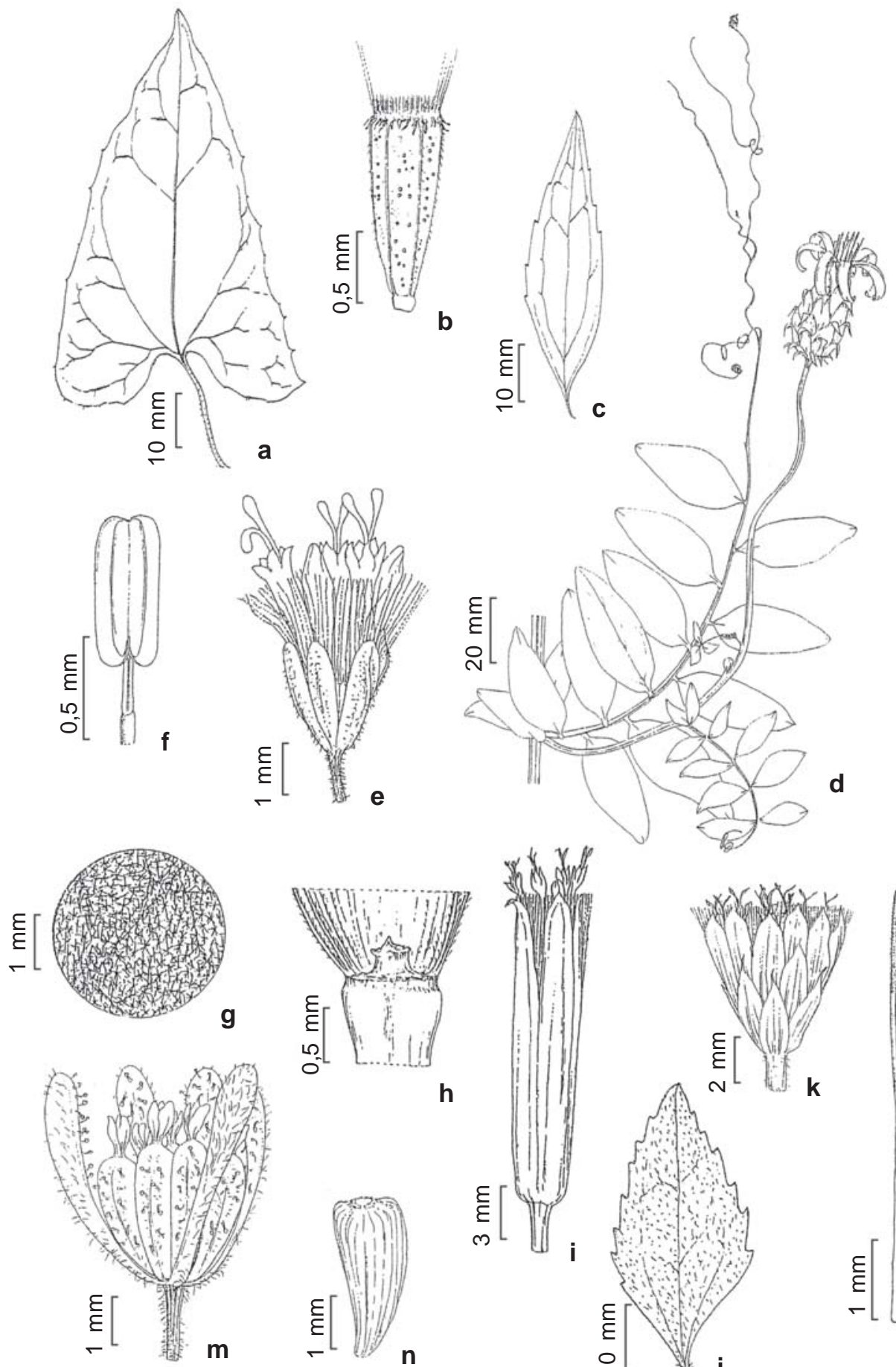
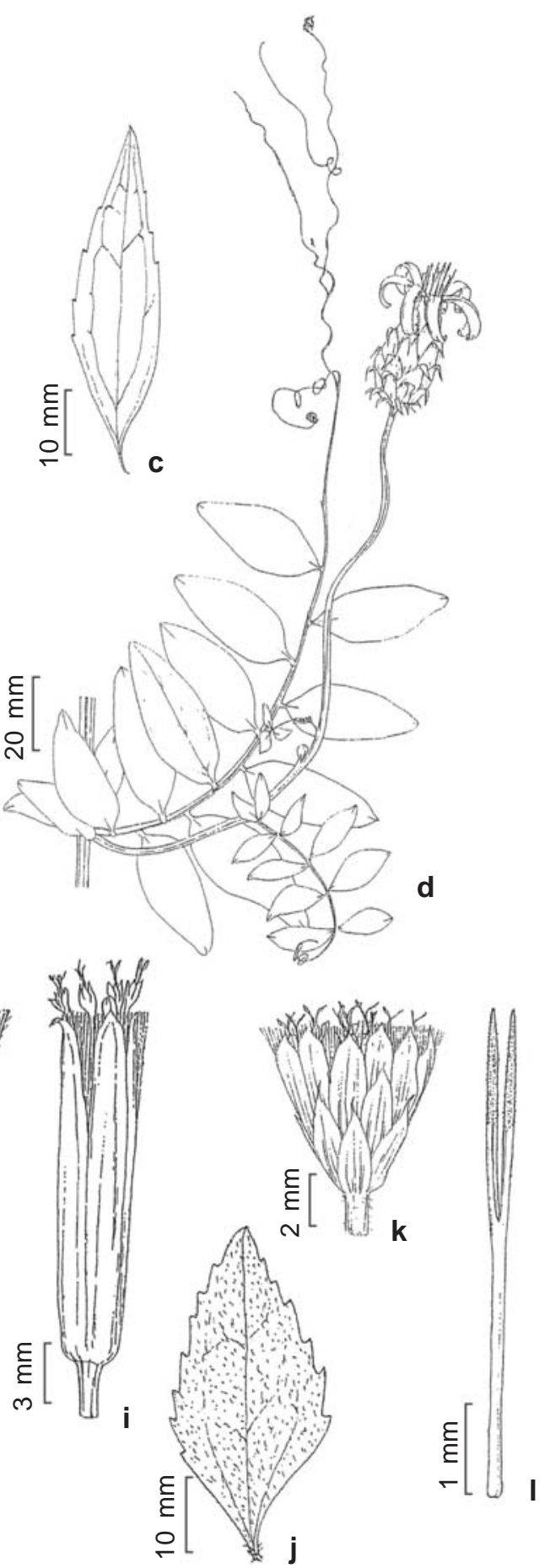

Figura 6 - a-b. Mikania salviaefolia - a. folha; b. cipsela. c. Mikania trinervis -c. folha. d. Mutisia speciosa -d. ramo com capítulo. e-f. Ophryosporus freyreysii - e.capítulo; f. antera. g-h. Piptocarpha macropoda - g. indumento; h. papilho bisseriado. i. Porophyllum ruderale - i. capítulo. j-1. Praxelis pauciflora -j. folha; k. capítulo; 1 . base dos ramos do estilete. m-n. Sigesbeckia orientalis - m. capítulo; n. cipsela.

Figure 6 - a-b. Mikania salviaefolia - a. leaf; b. cypselae. c. Mikania trinervis - c. leaf. d. Mutisia speciosa - d. branch with head. e-f. Ophryosporus freyreysii - e. head; f. anther. g-h. Piptocarpha macropoda - g. indument; h. bisseriate pappus. i. Porophyllum ruderale - i. head. j-1. Praxelis pauciflora - j. leaf; k. head; l. base style. m-n. Sigesbeckia orientalis - m. head; n. cypselae. 
folíolos 5-7 pares, subopostos ou alternos, membranáceos, elípticos ou lanceolados, 2,2-4,5 $\times 0,7-1,5 \mathrm{~cm}$, face adaxial esparso-tomentosa, face abaxial alvo-tomentosa, ápice obtuso ou agudo, margem inteira, base cuneada, sésseis. Capítulos heterógamos, radiados, terminais, pedunculados, pedúnculo 10-14 cm compr., tomentoso a glabro; receptáculo plano, glabro; invólucro campanulado, 3-4,5 × 1,5-2,3 cm; brácteas involucrais dispostas em 5-7 séries, externas ovadas, revolutas, internas oblongas, ápice revoluto, ambas com ápice obtuso, tomentoso. Flores da margem pistiladas, bilabiada 10-12, magenta, tubo da corola ca. 3 cm compr., glabro, lígula ca. 2 cm compr., glabra. Flores do centro hermafroditas, tubulosas, amarelo claro, tubo da corola ca. 2 cm compr., glabro, lobos ca. 0,8 cm compr., glabro. Cipsela cilíndrico-fusiforme ca. $2,3 \mathrm{~cm}$ compr.; papilho de cerdas plumosas, ca. 2,5 cm compr., acinzentado.

Material examinado: Viçosa, MP, Margem da lagoa principal, 14.VI.2005, fl. e fr., S.C. Ferreira et al. 126 (VIC); Trilha principal, 29.IX.2004, fl., S.C. Ferreira et al. 03 (VIC); 20.IX.2002, fl., P.B. de Souza et al. (VIC 29.530).

Floresce de junho a outubro, tendo beija-flores como visitantes florais. A espécie encontra-se distribuída nas matas do Sudeste e Sul do Brasil, Leste do Paraguai e Sul da Argentina (Cabrera, 1965).

28. Ophryosporus freyreysii (Thunb.) Baker in Mart., Fl. Bras. (2):188. $1876 . \quad$ Fig. 6e-f Eupatorium freyreysi Thunb., Pl. Bras. 2: 25.1818

Subarbustos escandentes, ca. 1,5 m alt., caule cilíndrico, verde e vináceo, glabro. Folhas opostas, inteiras, opostas, membranáceas, estreitamente ovadas a lanceoladas, 6-8,5 $\times$ 1,8-3 cm, concolores, ambas as faces glabras, venação triplinérvia, ápice agudo a acuminado, margem serreada, base cuneada, pecíolo 0,5$1 \mathrm{~cm}$ compr., pubescente. Capítulos homógamos, discóides, dispostos em cimas corimbiformes, pedunculados; receptáculo convexo, glabro; invólucro campanulado ca. 2,5 $\times 1,5 \mathrm{~mm}$, brácteas involucrais 5 , dispostas em
1 série, oblongas, pubescentes, ápice obtuso, margem ciliada. Flores hermafroditas, 5; corola infundibuliforme, ca. 2,5 $\mathrm{mm}$ compr., pubescente; apêndice da antera inconspícuo, dividido em dois lobos diminutos, base obtusa; ramos do estilete com ápice capitado, enegrescido, base não dilatada. Cipsela ca. 1,5 mm compr., pubescente; papilho ca. $2 \mathrm{~mm}$ compr., cerdoso, com cerdas finas.

Material examinado: Viçosa, MP, Trilha principal, 1.X.2004, fl. e fr., S.C. Ferreira \& M. Eiterer 16 (VIC); 1.X.2004, fl., S.C. Ferreira \& M. Eiterer $18 a$ (VIC); 5.VIII.2005, fl., S.C. Ferreira \& E.C. Cabrini 152 (VIC); 25.VIII.2005, fl., S.C. Ferreira \& D. Francino 166 (VIC).

Floresce de agosto a outubro. Restrita ao Brasil, a espécie é considerada, até o momento, endêmica do estado de Minas Gerais (Baker 1876; King \& Robinson 1987).

\section{Piptocarpha macropoda (DC) Baker in} Mart., Fl. bras. 6(2): 123. $1873 . \quad$ Fig. 6g-h Vernonia macropoda DC., Prodr. 5: 19. 1836.

Árvores ca. $8 \mathrm{~m}$ alt.; ramos lisos, acinzentados, estrelado-tomentosos. Folhas coriáceas, ovadas a elípticas, 7,5-12,8×4-5,8 cm, discolores, face adaxial glabra, face adaxial cinérea estrelado-tomentosa, ápice agudo, margem inteira, levemente revoluta, base cuneada, pecíolo 1,52,2 cm compr., indumento estrelado-tomentoso. Inflorescências glomeruliformes, eixos das inflorescências estrelado-tomentosos; capítulos homógamos, discóides, sésseis; receptáculo convexo, epaleáceo; invólucro turbinado, 6-7 mm compr., brácteas involucrais 33-36, dispostas em 4-5 séries, brácteas externas ovadas, seríceas, ápice agudo, margem ciliada, as internas completamente caducas, linearlanceoladas, ápice seríceo, obtuso. Flores 1619; corola tubulosa, amarela, ca. $5 \mathrm{~mm}$ compr., glabra, lobos ca. 2 mm compr., lanceolados; anteras caudadas. Cipsela 3-4-costada, ca. 3,5 mm compr., glabra; papilho 2-seriado com cerdas externas 1,5 mm compr., paleáceas, cerdas internas ca. $6 \mathrm{~mm}$ compr., alvas.

Material examinado: Viçosa, MP, 20.IX.2002, fl. e fr., P.B. de Souza et al. (VIC 29.532). 
Floresce em setembro. Ocorre em Goiás, Distrito Federal, Minas Gerais, Bahia, Rio de Janeiro, São Paulo, Paraná, Santa Catarina, regiões costeiras do sul e sudeste e de altitude no Centro-Oeste (Nakajima 2000).

30. Porophyllum ruderale (Jacq.) Cass., Dict. Sci. Nat. 43: 56. $1826 . \quad$ Fig. 6i Kleinia ruderalis Jacq., Enum. Syst. Pl. 28. 1760.

Ervas anuais, ca. $50 \mathrm{~m}$ alt.; caule estriado, glabro, verde a arroxeado. Folhas opostas membranáceas, elípticas, 2,2-4,5×0,9-1,7 cm, ambas as faces glabras, pontuadas de glândulas trasnlúcidas ao longo da margem, ápice obtusomucronado, margem crenada a ondulada, base cuneada, pecíolo 1-1,8 cm compr. Capítulos homógamos, discóides, em panículas, pedunculados, pedúnculos 2,9-4cm compr.; receptáculo plano, glabro; invólucro cilíndrico ca. 2,0 × 0,6cm, brácteas involucrais 5, com glândulas translúcidas, oblongas, glabras, ápice agudo. Flores com corola tubulosa, esverdeada a lilás, ca. 1,2 cm compr., glabra; anteras curtamente calcaradas, acaudadas. Cipsela ca. $1 \mathrm{~cm}$ compr., pubescente, carbonizada, atenuada na base; papilho ca. $1 \mathrm{~cm}$ compr, alvo. Material examinado: Viçosa, MP, Trilha principal, 16.V.2005, fl. e fr., S.C. Ferreira \& I. Rodrigues 111 (VIC).

Floresce em maio. Distribuída por toda América tropical (Cabrera 1974), sendo considerada ruderal por Lorenzi (1991).

31. Praxelis pauciflora (Kunth) R.M. King \& H. Rob. Phytologia 20: 195. 1970.

Fig. 6j-1

Eupatorium pauciflorum Kunth. in H.B.K., Nov. Gen. Sp. 4:94.1818.

Ervas eretas, ca. $4 \mathrm{~cm}$; ramos cilíndricos, estriados, pilosos. Folhas opostas, membranáceas, ovadas, $2,5-3,8 \times 0,8-2,1 \mathrm{~cm}$, face adaxial estrigosa, face abaxial esparsamente pilosa, pontuada de glândulas, trinérvia, ápice agudo, margem serreada $2 / 3$ distal, base cuneada, pecíolo 4-8 mm compr., piloso. Capítulos homógamos, discóides, dispostos em cimeiras corimbiformes, pedunculados; receptáculo cônico, glabro; invólucro campanulado, ca. 7 $\times 10 \mathrm{~mm}$, brácteas involucrais 16-19, dispostas em 3 séries, caducas, desiguais em comprimento, externas gradualmente menores, todas oblongas, glabras, margem hialina, ápice atenuado. Flores 45-46; corola tubulosa, lilás, ca. $3 \mathrm{~mm}$ compr., glabra, lobos glabros; anteras com base obtusa; ramos do estilete clavados, base não dilatada, glabra. Cipsela ca. 2,2 mm compr., pilosa, 5costada; papilho ca. $3 \mathrm{~mm}$ compr., alvo.

Material examinado: Viçosa, MP, Trilha principal do aceiro, 23.II.2005, fl. e fr., S.C. Ferreira et al. 73 (VIC).

Floresce em fevereiro. A espécie é amplamente distribuída na América do Sul. No Brasil, pode ser encontrada no Pará, Piauí, Maranhão, Ceará, Bahia, Goiás, Mato Grosso e São Paulo, não sendo citada para Minas Gerais por Barroso (1950).

32. Sigesbeckia orientalis L., Sp. Pl. 1:900. 1753.

Fig. 6m-n

Ervas ca. $30 \mathrm{~m}$ alt.; caule cilíndrico, fistuloso, levemente estriado, tomentoso. Folhas opostas, membranáceas, ovadas, 3-6 × 1,2$1,5 \mathrm{~cm}$, face adaxial pubescente, face abaxial tomentosa, densamente glandulosa, ápice agudo, margem denteada ou crenada, base atenuada, pecíolo até $0,7 \mathrm{~cm}$ compr. Capítulos heterógamos, radiados, dispostos em panículas, pedunculados, pedúnculos $0,8-1,7 \mathrm{~cm}$; receptáculo levemente convexo, paleáceo; invólucro campanulado ca. $4 \times 10 \mathrm{~mm}$, brácteas foliáceas espatuladas ao longo do pedúnculo, brácteas involucrais dispostas em 2 séries, brácteas externas espatuladas, revestida por tricomas glandulares, internas obovadas, ambas densamente cobertas por tricomas glandulares, ápice obtuso. Flores do raio pistiladas, corola amarela, tubo ca. 1 mm compr., pontuada de tricomas glandulares, limbo 0,7-1 mm compr., pontuado de glândulas, 3-denteado. Cipsela ca. $3 \mathrm{~mm}$ compr., glabra. Flores do disco hermafroditas, tubulosas, corola amarela, 1,5 mm compr., pontuada de glândulas, ápice 5-denteado; anteras com base obtusa, ramos do estilete curtos, triangulares. Cipsela oblongo-ovóide ca. $3 \mathrm{~mm}$ compr., glabra; papilho ausente.

Material examinado: Viçosa, MP, Trilha principal, 30.X.1989, fl., M. Thiengo 40 (VIC). 
Floresce em outubro. Considerada por Barroso (1959) como ruderal nas regiões tropicais.

33. Sonchus oleraceus L., Sp. P1. 1: 794. 1753. Fig. 7a

Ervas anuais, latescentes, 0,5-1,4 $\mathrm{m}$ alt.; caule cilíndrico, fistuloso, estriado. Folhas basais profundamente partidas, lobos deltóides, $10-12 \times 3,2-6 \mathrm{~cm}$, ambas as faces glabras, ápice agudo, margem denteada, base atenuada ou amplexicaule; folhas superiores profundamente partidas ou inteiras, lobos ovados ou lanceolados, 6-10,5×2-6,1 cm, ambas as faces glabras, ápice agudo, margem denteada, base amplexicaule . Inflorescência corimbiformes, homógamos, ligulados, pedunculados; receptáculo plano, glabro; invólucro cilíndrico-campanulado, ca. $1,1 \times 0,6 \mathrm{~cm}$; brácteas involucrais dispostas em 5 séries, lanceoladas, glabrescentes, ápice agudo, margem inteira. Flores liguladas, corola amarela, tubo ca. $6 \mathrm{~mm}$ compr., piloso, limbo ca. $3 \mathrm{~mm}$ compr., glabro; anteras com base sagitada; ramos do estilete lineares. Cipsela 2-3 mm compr., ovadas, glabras; papilho cerdoso ca. $5 \mathrm{~mm}$, alvo. Material examinado: Viçosa, MP, Margem da lagoa menor, 11.III.2005, fl. e fr., S.C. Ferreira 83 (VIC); Margem da lagoa principal, 14.II.2005, fl., S.C. Ferreira \& D. Francino 68 (VIC); Trilha do aceiro, 23.II.2005, fl., S.C. Ferreira et al. 74 (VIC); Trilha principal, 14.II.2005, fl., S.C. Ferreira \& D. Francino 64 (VIC); 25.XI.2002, fl.,A.D. Koehler et al. (VIC 29522).

Floresce durante todo o ano. Cabrera (1974) cita a espécie paraEuropa eAméricas. Baker(1882) indica $S$. oleraceus como espécie cultivada.

34. Sphagneticola trilobata (L.) Pruski, Mem. New York Bot. Gard. 87: 114. 1996.

Silphium trilobatum L., Syst. Nat. (ed. 10) 2: 1233. 1759 .

Ervas ca. 25 malt.; caule cilíndrico, fistuloso, estriado, esparso-tomentoso, nós proximais com raízes. Folhas opostas, membranáceas, ovadas a elípticas, 3,5-10,4×1,6-4,4 cm, ambas as faces estrigosas, face adaxial pontuada com glândulas, ápice 3-lobado, lobos agudos, margem serreada, base cuneada a atenuada, sésseis ou com pecíolo até $0,5 \mathrm{~cm}$ compr. Capítulos heterógamos, radiados, sotitários, terminais, pedunculados, pedúnculo 6-15,5 cm; receptáculo convexo, paleáceo, páleas lanceoladas, conduplicadas; invólucro campanulado ca. $8 \times$ $6 \mathrm{~mm}$, brácteas involucrais 10-12, dispostas em 2 séries, oblanceoladas, pubescentes, ápice agudo, margem ciliada. Flores do raio pistiladas, 15-18, corola amarelo-escura, tubo ca. $1 \mathrm{~mm}$ compr., glabra, limbo $1 \mathrm{~cm}$ compr., 3-lobado. Cipsela ca. 2 mm compr., levemente comprimida, pontuada de glândulas. Flores do disco hermafroditas, corola tubulosa, amarelo-escura, 4 mm compr., glabra, ápice 5-denteado, piloso internamente. Cipsela ca. $3 \mathrm{~mm}$ compr., pontuada de glândulas, papilho com corona fimbriada.

Material examinado: Viçosa, MP, Trilha principal, 13.X.1989, f1., M. Thiengo 02 (VIC); 17.XII.2005, fl., S.C. Ferreira \& E. Duarte 39 (VIC); 14.II.2005, fl., S.C. Ferreira \& D. Francino 70 (VIC); 11.III.2005, fl., S.C. Ferreira 78 (VIC).

Floresce ao longo de todo o ano, sendo considerada como planta ruderal por Lorenzi (1991). Segundo D’Arcy (1975), a espécie ocorre naturalmente no interior de locais perturbados e úmidos. É considerada nativa dos neotrópicos, sendo cultivada atualmente como ornamental em vários países (D’Arcy 1975).

35. Spilanthes acmella (L.) Murray, Syst. Veg. 610. 1774.

Verbesina acmella L., Sp. Pl. 2: 901-902. 1753.

Ervas ca. $50 \mathrm{~m}$ alt.; caule cilíndrico, fistuloso, estriado, esparso-pubescente. Folhas opostas, membranáceas, ovadas a elípticas, 4,4-7,5 $\times$ $1,9-4,4 \mathrm{~cm}$, ambas as faces glabrescentes, ápice agudo, margem irregularmente serreada, base levemente atenuada, pecíolo 1-2 cm compr. Capítulos homógamos, discóides, terminais, pedunculados, pedúnculos 3-13,5 cm compr.; receptáculo longamente convexo, paleáceo, páleas oblongas, côncavas; invólucro campanulado ca. $4 \times 8 \mathrm{~mm}$, brácteas involucrais 10-11, dispostas em 2 séries, ovadas, glabras, ápice obtuso, margem hialina. Flores hermafroditas, tubulosas; corola alva, ca. 1,5 mm compr., glabra, ápice 5-lobado; anteras combase obtusa, tecas enegrescidas; ramos do estilete lineares. Cipsela fortemente comprimidas, bordas longamente ciliadas, ca. $2 \mathrm{~mm}$ compr., glabra; papilho ca. 0,5 mm, 3-aristado. 


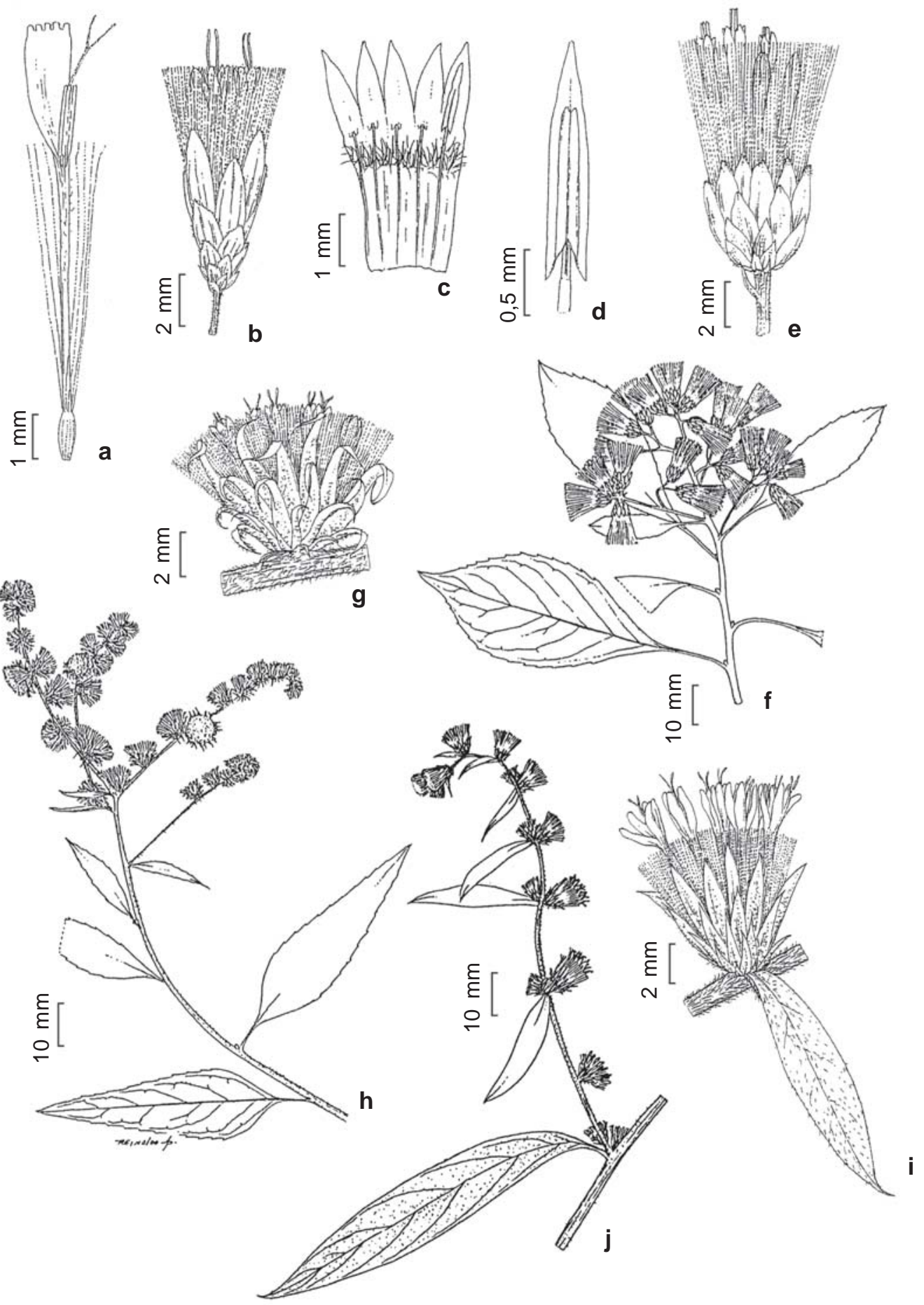

Figura 7 - a. Sonchus oleraceus - a. flor. b-d. Steyermarkina pyrifolia - b. capítulo; c. face interna do tubo da corola; d. antera. e-f. Vernonia amygdalina - e. capítulo; f. ramo com capítulo. g-h. Vernonia geminata - g. capítulo; h. ramo com capítulo. i-j. Vernonia salzmanni - i. capítulo; j. ramo com capítulo.

Figure 7 - a. Sonchus oleraceus - a. flower. b-d. Steyermarkina pyrifolia - b. head; c. face interns of the tube of the corolla; d. anther. e-f. Vernonia amygdalina - e. head; f. branch with head. g-h. Vernonia geminata - g. head; h. branch with head. $\mathrm{i}$-j. Vernonia salzmanni - i. head; j. branch with head. 
Material examinado: Viçosa, MP, Trilha principal, 1.X.2004, fl., S.C. Ferreira 17 (VIC).

Floresce em outubro. Distribui-se nas regiões tropicais, ocorrendo no Brasil nos estados do Amazonas, Pará, Pernambuco, Goiás, Minas Gerais e Rio de Janeiro (Baker 1884).

36. Steyermarkina pyrifolia (DC.) R.M. King \& H. Rob. Phytologia 22: 44. 1971.

Fig. 7b-d

Eupatorium pyrifolium DC., Prodr.: 153. 1836.

Subarbustos escandentes ou apoiantes; ramos cilíndricos, lisos, ferrugíneos, pubescentes. Folhas opostas, concolores, cartáceas, ovadas a elípticas, 3,5-7,3 × 1,6-3,7 cm, ambas as faces glabras, quintoplinérvias, ápice acuminado, margem inteira, base cuneada, raro obtusa, pecíolo 4$10 \mathrm{~mm}$ compr., pubescente-ferrugíneos. Capítulos homógamos, discóides, dispostos em panículas de cimeiras corimbiformes, subsésseis ou curto-pedunculados; receptáculo convexo, glabro; invólucro cilíndrico-campanulado, 6-7 $\times 2-4 \mathrm{~mm}$, brácteas involucrais 16-21, dispostas em 4 séries, externas ovadas, ciliadas, internas oblongo-lanceoladas, glabras, ápice obtuso. Flores 5; corola alva, ca. $5 \mathrm{~mm}$ compr., esparsopubescente externamente, hirsuta internamente na região dos filetes, lobos 3 vezes mais longos que largos, glabros; anteras com base sagitada; ramos do estilete lineares, base não dilatada, glabra. Cipsela ca. $3 \mathrm{~mm}$ compr., pubérula, 5costada; papilho ca. $5 \mathrm{~mm}$ compr., alvo.

Material examinado: Viçosa, MP, Trilha principal do aceiro, fl. e fr., R.M. Carvalho-Okano et al. (VIC 14690).

Floresce de julho a setembro (Esteves 2001). No Brasil, ocorre no Mato Grosso do Sul, Minas Gerais, Rio de Janeiro, São Paulo, Paraná e Santa Catarina (Esteves 2001).

37. Tilesia baccata (L.) Pruski, Novon 6(4): 414. 1996.

Coreopsis baccata L., Pl. Surin. 14. 1775.

Arbustos procumbentes, alcançando 2$3 \mathrm{~m}$ alt.; caule anguloso, estriado, hirsuto. Folhas opostas, membranáceas, ovadas a elípticas, $8,1-19,5 \times 3,4-9,5 \mathrm{~cm}$, face adaxial estrigosa, face abaxial hirsuta, ápice agudo a acuminado, margem serreada a crenada, base curtoatenuada a cuneada, pecíolo 1,6-4,2 cm compr. Capítulos heterógamos, radiados, dispostos em cimeiras, terminais, pedunculados, pedúnculos 1,1-3,5 cm; receptáculo levemente convexo, paleáceo, páleas oblongas, envolvendo as cipselas marginais; invólucro hemisférico ca. $1 \times 2 \mathrm{~cm}$, brácteas involucrais dispostas em 3 séries, lanceoladas, hirsutas, ápice agudo, margem inteira. Flores do raio neutras, amarelas; tubo ca. $1 \mathrm{~mm}$ compr., glabro, limbo ca. $1 \mathrm{~cm}$ compr., 3-lobado. Cipsela ca. $2 \mathrm{~mm}$ compr., glabra. Flores do disco hermafroditas, amarelas; corola $5 \mathrm{~mm}$ compr., pubescente, ápice 5-denteado; anteras enegrescidas, base obtusa; ramos do estilete lineares, hirsutos. Cipsela obpiramidal, 4-angulosa, túrgida, ápice truncado, madura ca. $4 \mathrm{~mm}$ compr., glabra; papilho ausente.

Material examinado: Viçosa, MP, Arredores da sede, 24.I.2005, fl., S.C. Ferreira \& I. Rogrigues 44 (VIC); Capinzal acima da lagoa, 5.I.1990, fl., $M$. Thiengo 69(VIC); Margem da lagoa, 29.X.2002, fl., P.B. de Souza et al. (VIC 29.529); Trilha no inteiro da mata, 25.I.2005, fl., S.C. Ferreira \& I. Rogrigues 52 (VIC); Trilha principal, 12.XI.2004, fl., S.C. Ferreira et al. 31 (VIC); 25.I.2005, fr., S.C. Ferreira \& I. Rogrigues 55 (VIC).

Floresce de outubro a janeiro. Ocorre no Paraguai, Peru e Brasil, nos estados da Amazônia, Pará, Maranhão, Pernambuco, Mato Grosso, Minas Gerais e Rio de Janeiro (Baker 1884).

38.Trixis divaricata (Kunth) Spreng., Syst. Nat. 3:501. 1826.

Perdicium divaricatum Kunth in H.B.K., Nov. Gen. Sp. 4:121. 1818.

Subarbustos ca. 2 malt.; ramos procumbentes, levemente estriados, tomentosos. Folhas, alternas, sésseis, membranáceas, lanceoladas, 4,5-11,1× 1-2,2 cm, discolores, face adaxial serícea, face abaxial albo-tomentosa, ápice agudo, margem denticulada, ciliada, pecíolo 1-4 mm compr., tomentoso. Inflorescência em panículas; homógamos; receptáculo plano, piloso; invólucro cilíndrico-campanulado, ca. 1,2 cm compr.; brácteas involucrais dispostas em 2 séries, externas 5-6, com glândulas estipitadas, internas 8-9, lanceoladas, ambas lanceoladas, com ápice agudo, margem 
ciliada. Flores hermafroditas 10-12, corola bilabiada, amarelo-clara, tubo da corola ca. $8 \mathrm{~mm}$ compr., externamente tomentoso, internamente pubescente na região da fauce, lobo externo reflexo a espiralado, lobointerno bipartido, espiralado, fauce e lobos com glândulas estipitadas; ramos do estilete com ápice truncado, penicilado. Cipsela 3 mm compr., cilíndrica, atenuada no ápice, com glândulas estipitadas; papilho $8 \mathrm{~mm}$ compr., palhete, caduco.

Material examinado: Viçosa, MP, Trilha principal, 22.VII.2005, fl., S.C. Ferreira \& D. Francino 141 (VIC); 5.VIII.2005, fl., fr., S.C. Ferreira \& E. Cabrini 155(VIC).

Floresce de julho a setembro. Distribui-se da América tropical até o norte da Argentina; no Brasil a espécie é encontrada no Mato Grosso, Minas Gerais, Rio de Janeiro, São Paulo e Paraná (Cabrera \& Klein 1973).
39. Vernonia Schreb., Gen. Pl. 2: 541. 1791. Ervas, arbustos ou árvores, raro lianas. Folhas alternas, raro opostas. Inflorescências compostas por capítulos homógamos, discóides, reunidos de forma variada ou solitários, axilares ou terminais; invólucro cilíndrico, campanulado ou turbinado, pauci a multisseriado, brácteas externas gradualmente menores; receptáculo plano ou levemente convexo, glabro. Flores 4muitas, hermafroditas; corola tubulosa, 5-lobada, branca, rósea, violácea ou purpúrea; anteras com base auriculada ou curto-sagitada; ramos do estilete lineares, agudos. Cipsela cilíndricoturbinada, 8-10-costada; papilho bisseriado, cerdoso, alvo, palhete ou avermelhado, cerdas externas paleáceas ou lineares, internas capilares ou achatadas, escabras.

\section{Chave para identificação das espécies de Vernonia da MP}

1. Brácteas foliáceas subtendendo os capítulos ao longo da inflorescência.

2. Lâmina foliar com nervura central plana e indumento pubérulo na face adaxial, ápice agudo, brácteas involucrais externas ovadas; cipsela com pontuações glandulares

4. V. macrophylla

2'. Lâmina foliar com nervura central sulcada e indumento estrigoso na face adaxial, ápice acuminado, brácteas involucrais externas lanceoladas; cipsela sem pontuações glandulares 6. V. salzmannii

1'. Brácteas foliáceas não subtendendo os capítulos ao longo da inflorescência.

3. Lâmina foliar com margem inteira e base cuneada.

4. Lâmina foliar 3,5-11,5 cm larg., pecíolo 1,5-4,1 cm compr.; inflorescência com capítulos dispostos congestamente . 2. V. discolor

4'. Lâmina foliar 1,7-3 cm larg., pecíolo 0,3-0,7 cm compr.; inflorescência com capítulos dispostos laxamente. 5. V. polyanthes

3'. Lâmina foliar com margem serreada ou denticulada e base atenuada.

5. Lâmina foliar elíptica, eixos secundários das inflorescências ramificados, capítulos pedunculados com 18-20 flores; brácteas involucrais externas ovadas e internas oblongas 1. V. amygdalina

5'. Lâmina foliar ovada a lanceolada, eixos secundários das inflorescências não ramificados, capítulos sésseis com 29-38 flores; brácteas involucrais externas e internas lanceoladas 3. V. geminata

39.1. Vernonia amygdalina Delile, Cent. $\mathrm{Pl}$. Afr. Voy. Méroé 41. 1826. Fig. 7e-f

Arbustos; ramos jovens cilíndricos, estriados, tomentosos. Folhas alternas, cartáceas a subcoriáceas, elípticas, 4,9-10,8 × $2,2-4,5 \mathrm{~cm}$, levemente discolores, face adaxial glabrescente, face abaxial tomentosa, pontuada de glândulas, ápice acuminado a agudo, margem serreada $2 / 3$ distal, base atenuada, pecíolo 0,6-3 cm compr., puberulento. Capítulos em panículas de cimas corimbiformes, curtamente pedunculados; eixos secundários ramificados; invólucro campanulado, ca. $6 \times 4 \mathrm{~mm}$, brácteas involucrais 30-35, dispostas em 5-6 
séries, persistentes, externas ovadas, pubescentes, internas oblongas, glabras, ápice acuminado; Flores 18-20; corola ca. 9 mm compr., pontuada de glândulas, lobos $2 \mathrm{~mm}$ compr., glabros. Cipsela ca. $2 \mathrm{~mm}$ compr., velutino, pontuado de glândulas; papilho palhete, série externa ca. 1 mm compr., série interna ca. $8 \mathrm{~mm}$ compr.

Material examinado: Viçosa, MP, Entrada da reserva, 15.V.1984, fl., E.A. Ferreira (VIC 8.691).

Floresce em maio. Espécie originária da África, sendo posteriormente introduzida nas Américas do Norte e do Sul (Leitão-Filho 1972). Vernonia amygdalina é considerada rara na MP, sendo coletada uma única vez a mais de 10 anos podendo, portanto, não ocorrer atualmente na área de estudo.

39.2. Vernonia discolor (Spreng.) Less. Linnaea 4:274. 1829.

Eupatorium discolor Spreng., Syst. Veg. 3: 412.1826.

Árvores, 6-10 m alt.; ramos jovens cilíndricos, estriados, tomentosos, pontuados de glândulas, acinzentados. Folhas alternas, cartáceas a subcoriáceas, elípticas a elípticolanceoladas, 9-24,8 ×3,5-11,5 cm, fortemente discolores, face adaxial pubescente, tomentosa na região da nervura central, face abaxial albotomentosa, pontuada de glândulas, ápice agudo, margem inteira, base cuneada, pecíolo 1,5-4,1 cm compr., tomentoso, pontuado de glândulas. Capítulos dispostos congestamente em panículas, pedunculados, pedúnculos gradualmente menores em direção a região apical; invólucro campanulado-cilíndrico, ca. $5 \times 3,5 \mathrm{~mm}$, brácteas involucrais 22-26, dispostas em 7-8 séries, externas ovadas, pubescentes, gradualmente menores, internas lanceoladas, pubescentes, ápice agudo a acuminado. Flores 9-11; corola branca, ca. $7 \mathrm{~mm}$ compr., glabra, lobos $1 \mathrm{~mm}$ compr., glabros. Cipsela ca. 2,5 mm compr., velutina pontuadade glândulas na região basal; papilho alvo, série externa ca. $1 \mathrm{~mm}$ compr., escamiforme, série interna ca. $7 \mathrm{~mm}$ compr.

Material examinado: Viçosa, MP, 10.X.1989, fl., $M$. Thiengo 13 (VIC); 22.X.2002, fl., P.B. de Souza et al. (VIC 29.533); Arredores da Sede, 29.IX.2004, fl., S.C. Ferreira et al. 08 (VIC); 28.VII.2005, fl., S.C.
Ferreira \& M. Godinho 147 (VIC); Trilha principal, 29.IX.2004, fl., S.C. Ferreira et al. 07 (VIC).

Floresce de julho a outubro. Ocorre nas Regiões Sul e Sudeste do Brasil (Cabrera \& Klein 1980) e no estado da Bahia (Moraes 1997).

39.3. Vernonia geminata Less., Linnaea 4:303.1829. Fig. 7g-h

Subarbustos, eretos ou escandentes, 0,6 1,6 $\mathrm{m}$ alt.; ramos cilíndricos, levemente estriados, tomentosos. Folhas alternas, membranáceas, ovadas a lanceoladas, 4-13 × 1,9-5,3 cm, discolores, face adaxial estrigosa a pubescente, face abaxial tomentosa, pontuada de glândulas inconspícuas, ápice acuminado, margem denticulada, base atenuada, pecíolo $0,2-1 \mathrm{~cm}$ compr., tomentoso. Capítulos em panículas, sésseis, eixos secundários não ramificados; invólucro campanulado, ca. $5 \times 5 \mathrm{~mm}$, brácteas involucrais 28-39, dispostas em 4-5 séries, persistentes, externas e internas lanceoladas, tomentosas, ápice atenuado, reflexo. Flores 2938; corola branca a lilás, ca. $5 \mathrm{~mm}$ compr., glabra, lobos $2 \mathrm{~mm}$ compr., esparsamente seríceos. Cipsela ca. 1 mm compr., serícea; papilho alvo, série externa ca. $1 \mathrm{~mm}$ compr., série interna ca. $4 \mathrm{~mm}$ compr. Material examinado: Viçosa, MP, Trilha principal, 13.X.1989, fl., M. Thiengo 15 (VIC); 20.IX.2005, fl. e fr., P.B. de Souza (VIC 29.534); 29.X.2002, A.D. Koehler et al. (VIC 29.524); 29.IX.2004, fl. e fr., S.C. Ferreira et al. 11 (VIC); 22.VII.2005, fl., S.C. Ferreira \& D. Francino 142 (VIC);28.VII.2005, fl., S.C. Ferreira \& M. Godinho 145(VIC); próximo a sede, 28.VII.2005, fl., S.C. Ferreira \& M. Godinho 146 (VIC); 5.VIII.2005, fl. e fr., S.C. Ferreira \& E. Cabrini 156 (VIC); 5.VIII.2005, fl. e fr., S.C. Ferreira 162 (VIC).

Floresce de julho a outubro. V. geminata é muito semelhante a $V$. scorpioides (Lam.) Pers., embora a segunda espécie não ocorra na área de estudo. Barroso (1959) separou as duas espécies utilizando a variação do ápice das brácteas involucrais, longo acuminado e denso piloso em $V$. geminata e agudo e levemente pubescente em $V$. scorpioides. Este caráter não mostrou variação nos espécimes da área estudada. Baseado na literatura conclui-se que para MP, os indivíduos estudados incluem-se predominantemente nas características 
morfológicas citadas para $V$. geminata. A espécie distribui-se nos estados de Minas Gerais e Rio de Janeiro (Barroso 1959).

39.4. Vernonia macrophylla Less., Linnaea 6: 668. 1831.

Arbustos, ca. $5 \mathrm{~m}$ alt.; ramos jovens levemente achatados, estriados. Folhas alternas, membranáceas, ovadas a elípticas, 11,5-29,1 $\times 4,6-16,2 \mathrm{~cm}$, discolores, face adaxial pubérula, com tricomas adpressos, face abaxial tomentosa, pontuada de glândulas, nervura central plana, ápice agudo, margem curto denteada, base obtusa a cuneada, pecíolo 1-3,5 cm compr., tomentoso. Capítulos em panículas, sésseis ou curtamente pedunculados, subtendidos por brácteas foliáceas, lanceoladas, 3,5-6,5×0,8$2 \mathrm{~cm}$, ápice agudo, face adaxial pubescente, face abaxial tomentosa, pontuada de glândulas, margem curto denteada; invólucro campanuladocilíndrico, ca. $10 \times 6 \mathrm{~mm}$, brácteas involucrais 26-34, dispostas em 6 séries, externas ovadas, gradualmente menores, internas lanceoladas, margem tomentosa, ápice agudo. Flores 20 23; corola branca, ca. 1,1 cm compr., glabra, lobos $3 \mathrm{~mm}$ compr., glabros. Cipsela ca. $2 \mathrm{~mm}$ compr., velutina, pontuada de glândulas; papilho palhete, série externa ca.1 mm compr., série interna ca. $5 \mathrm{~mm}$ compr.

Material examinado: Viçosa, MP, Trilha principal, 13.V.1985, fl. e fr., M.F. Vieira et al. 211 (VIC).

Floresce em maio. Barroso (1959) citou a espécie apenas para o Rio de Janeiro, porém de acordo com Baker (1873), a espécie distribuise também no estado de Minas Gerais.

39.5. Vernonia polyanthes Less., Linnaea 6:631. 1831.

Arvoretas 2-3 m alt.; ramos jovens pentagonais, estriados, acinzentados, pubescentes, glandulosos. Folhas alternas, subcoriáceas, lanceoladas, $5,1-13,8 \times 1,7-3 \mathrm{~cm}$, discolores, face adaxial estrigosa, face abaxial tomentosa, pontuada de glândulas, ápice agudo, margem inteira, base cuneada, pecíolo 3-7 mm compr. Capítulos dispostos laxamente em panículas de cimas corimbiformes; invólucro campanulado, ca. $5 \times 3,5 \mathrm{~mm}$, brácteas involucrais 35-36, dispostas em 4-6 séries, persistentes, externas ovadas, internas lanceoladas, metade distal tomentosa, ápice acuminado, margem ciliada. Flores 22-24; corola branca, ca. 5 mm compr., glabra, lobos $1 \mathrm{~mm}$ compr., reflexos, glabros. Cipsela ca. $2 \mathrm{~mm}$ compr., glabra, densamente pontuada de glândulas; papilho palhete, série externa ca. 1,5 mm compr., série interna ca. $4,5 \mathrm{~mm}$ compr.

Material examinado: Viçosa, MP, Margem da lagoa principal, 30.VI.2005, fl., S.C. Ferreira 133 (VIC); 22.VII.2005, fl., S.C. Ferreira 137 (VIC); Trilha do aceiro, 12.XI.2004, fr., S.C. Ferreira et al. 28 (VIC).

Floresce de junho a julho, ocorrendo em áreas perturbadas. Ocorre nos estados da Bahia, Minas Gerais, Goiás, Mato Grosso, Paraná e São Paulo (Leitão-Filho 1972).

39.6. Vernonia salzmanni DC., Prodr. 5: 55. 1836.

Fig. 7i-j

Subarbustos, 0,6-2,3 m alt.; ramos jovens cilíndricos, estriados, tomentosos, glandulares. Folhas alternas, cartáceas a subcoriáceas, elípticas a lanceoladas, 6,5-11,5 ×1,5-4,5 cm, discolores, face adaxial estrigosa, com tricomas adpressos, face abaxial tomentosa, pontuada de glândulas, nervura central sulcada, ápice acuminado, margem curtamente denteada, base cuneada, pecíolo 4 $8 \mathrm{~mm}$ compr., tomentoso. Capítulos em panículas, sésseis, subtendidos por brácteas foliáceas, lanceoladas, 2,5-7,5 ×0,5-1,4 cm, ápice acuminado, face adaxial estrigosa, face abaxial tomentosa, pontuada de glândulas, margem curtamente denteada; invólucro campanulado, ca. $7 \times 7 \mathrm{~mm}$, brácteas involucrais 28-29, dispostas em 4-5 séries, lanceoladas, externas glabras, internas com ápice tomentoso, acuminado. Flores 20-25; corola lilás a roxa, 7-8 mm compr., glabra, lobos $3 \mathrm{~mm}$ compr., glabros. Cipsela ca. $2 \mathrm{~mm}$ compr., serícea, sem pontuações glandulares; papilho alvo, série externa ca.1 mm compr., série interna ca. $5 \mathrm{~mm}$ compr. Material examinado: Viçosa, MP, Trilha do aceiro, 16.V.2005, fl., S.C. Ferreira \& I. Rodrigues 117 (VIC); Trilha circuito das caminhadas, 12.V.2005, fl., S.C. Ferreira 110(VIC); Trilha dos Gigantes, 14.VI.2005, fr., S.C. Ferreira et al. 129 (VIC); Trilha principal, 1.X.2004, fr., S.C. Ferreira \& M. Eiterer 14 (VIC); 
17.IV.2005, fl., S.C.Ferreira 103 (VIC); 3.V.2005, fl., S.C. Ferreira 107 (VIC).

Floresce de abril a junho. Baker (1873) cita a espécie para Mato Grosso, Bahia, Minas Gerais, Rio de Janeiro e São Paulo.

\section{Considerações Finais}

Na MP, a família Asteraceae está representada por 61 espécies circunscritas a 39 gêneros e 10 tribos, sendo que os gêneros melhor representados são Mikania (oito spp.), Baccharis (sete spp.), Vernonia (seis spp.) e Chromolaena (três spp.). A tribo mais rica em número de gênero e espécies é Eupatorieae, com 22 espécies distribuidas em 12 gêneros, seguida por Heliantheae (11 spp. e 10 gêneros), Asteraeae (nove spp. e três gêneros) e Vernonieae (oito spp. e três gêneros).

As espécies herbáceas foram as mais abundantes (26 spp.), seguidas pelos subarbustos (16 spp.), trepadeiras (nove spp.) e arbustos (seis spp.). O hábito arbóreo foi observado em apenas quatro espécies da família Asteraceae na MP.

Quanto à distribuição geográfica das espécies que ocorrem na Mata do Paraíso, 15 apresentam-se amplamente distribuídas, nove ocorrem na região neotropical, 18 estão distribuídas na América do Sul e 19 apresentam distribuição restrita ao Brasil. Foi, também, possível constatar que Vernonia geminata e V. macrophylla apresentam distribuição restrita a Minas Gerais e Rio de Janeiro e Ophryosporus freyreysii, é endêmica do estado de Minas Gerais, ressaltando a importância de levantamentos floristicos no estado.

\section{Agradecimentos}

À Coordenação de Aperfeiçamento Pessoal de Nível Superior (CAPES), a bolsa concedida à primeira autora; a Reinaldo $\mathrm{A}$. Pinto as ilustrações; aos funcionários do herbário VIC, da Universidade Federal de Viçosa; e aos curadores dos herbários visitados.

\section{REFERÊNCIAS BIBLIOGRÁFICAS}

Andenberg, A.A.; Baldwin, B.G.; Bayer, R.G.; Breitwieser, J.; Jeffrey, C.; Dillon, M.O.; Eldeñas, P.; Funk, V.; Garcia-Jacas, N.; Hind, N.J.N.; Karis,
P.O.; Lack, H.W.; Neson, G.; Nordenstam, B.; Oberprieler, C.H.; Panero, J.L.; Puttock, C.; Robinson, H.; Stuessy, T.F.; Susanna, A.; Urtubey, E.; Vogt, R.; Ward, J. \& Watson, L.E. 2007. Compositae. In: Kadereit, J.W. \& Jeffrey, C. (eds.). Flowering plants Eudicots Asterales. Vol III. The families and genera of vascular plants, Kubitski, K. (ed.). Springer, Verlag. Pp. 61-588.

APG II. The Angiosperm Phylogeny Group. 2003. An update of the angiosperm phylogeny group classification for the orders and families of flowering plants. Botanical Journal of the Linnean Society 141: 399-436.

Baker, J.G. 1873. Compositae I: Vernoniaceae. In: Martius, C.P. von \& Eichler, A.W. \& Urban, I. (eds.). Flora brasiliensis. Munchen, Wien, Leipzig, 6(2): 1-179.

Baker, J.G. 1876. Compositae II: Eupatoriaceae. In: Martius, C.P. von \& Eichler, A.W. \& Urban, I. (eds.). Flora brasiliensis. Munchen, Wien, Leipzig, 6(2): 181-374.

Baker, J.G. 1882. Compositae III: Asteroideae, Inuloideae. In: Martius, C.P. von \& Eichler, A.W. \& Urban, I. (eds.). Flora brasiliensis. Munchen, Wien, Leipzig 6(3): 1-134.

Baker, J.G. 1884. Compositae IV: HelianthoideaeMutisiaceae. In: Martius, C. P. von \& Eichler, A. W. \& Urban, I. Flora brasiliensis. Munchen, Wien, Leipzig, 6(3): 138-398.

Barroso, G.M. 1950. Considerações sobre o gênero Eupatorium. Arquivos do Jardim Botânico do Rio de Janeiro 10: 13-116.

Barroso, G.M. 1958. Mikanieae do Brasil. Arquivos do Jardim Botânico do Rio de Janeiro 16: 239-333.

Barroso, G.M. 1959. Flora Ilustrada do Rio de Janeiro - Compositae. Rodriguésia 21/22: 69-147.

Barroso, G.M. 1975-76. Compositae - Subtribo Baccharidinae Hoffmann. Estudo das espécies ocorrentes no Brasil. Rodriguésia 28: 3-273.

Barroso, G.M; Peixoto, A.L.; Costa, C.G.; Ichaso, C.L.F.; Guimarães, E.F. \& Lima, H.C. 1991. Sistemática das angiospermas do Brasil. Vol. 3. Editora UFV. 326p.

Bremer, K. 1994. Asteraceae: cladistics and classification. Timber Press, Portland. 429p.

Busey, P. 1975. Vernonieae-Elephantopodinae. In: D’Arcy, W.G. (eds.). Flora of Panama: Compositae 62: 873-888.

Cabrera, A.L. 1963. Flora de la provincia de Bueno Aires. Colección Científica del INTA, Buenos Aires 4: 1-443. 
Cabrera, A.L. 1965. Revisión del género Mutisia (Compositae). Opera Lilloana 13:1-222.

Cabrera, A.L. 1974. Flora Ilustrada de Entre Rios (Argentina). Colección Científica del INTA, Bueno Aires. 6: 106-554.

Cabrera, A.L. \& Klein, R.M. 1973. Compostas 1 - Tribo Mutisieae. In: Reitz, R. (ed.). Flora Ilustrada Catarinense. Pp. 1-124.

Cabrera, A.L. \& Klein, R.M. 1980. Compostas 2 Tribo Vernonieae. In: Reitz, R. (ed.). Flora Ilustrada Catarinense. Pp. 226-408.

Cabrera, A.L. \& Klein, R.M. 1989. Compostas 3 Tribo Eupatorieae. In: Reitz, R. Flora Ilustrada Catarinense. Pp. 409-760.

Cronquist, A. 1988. The evolution and classification of flowering plants. 2 ed. The New York Botanical Garden, New York. 555p.

D' Arcy, W.G. 1975. Heliantheae: Helianthinae; Coreopsidinae. In: D'Arcy, W.G. Flora do Panama: Compositae 62: 1053-1056.

Esteves, R.L. 2001. O gênero Eupatorium s.l (Compositae-Eupatorieae) no estado de São Paulo. Tese de Doutorado. Universidade Estadual de Campinas, Campinas. 314p.

Esteves, R.L. \& Barroso, G.M. 1996. Compositae. In: Lima, M.P.M. \& Guedes-Bruni, R.R. (eds.). Reserva Ecológica de Macaé de Cima. Instituto de Pesquisas Jardim Botânico, Rio de Janeiro. Pp. 189-245.

Hattori, E.K.O. 2008. A família Asteraceae na Estação de Pesquisa e Desenvolvimento Ambiental Galheiros, Perdizes, Minas Gerais, Brasil. Rodriguésia 59(4): 687-749.

Hind, D.J.N. 1995. Compositae. In: Stannard, B. L. (ed.). Flora of Pico das Almas - Chapada Diamantina, Bahia Brazil. Kew, Royal Botanic Gardens . Pp. 175-278.

Hind, D.J.N. 2003. Flora de Grão Mogol: Compositae. Boletim Botânica Universidade de São Paulo 21(1): 194-234.

Holmgren, P.K.; Holmgren, N.H. \& Barnett, L.C. 1990. Index Herbariorum: Part I: The herbaria of the world. New York Botanical Garden, New York. 693p.

Holmes, W.C. 1995. A review preparatory to an infrageneric classification of Mikania (Eupatorieae). In: Hind, D. J. N.; Jeffrey \& Pope, G.V. (eds.). Advances in compositae systematics. Royal Botanic Gardens, Kew. Pp. 239-254.

King, R.M. \& Robinson, H. 1987. The genera of the Eupatorieae (Asteraceae). Missouri Botanical Garden, St. Louis. 581p.
Leal-Filho, N. 1992. Caracterização do banco de sementes de três estádios de uma sucessão vegetal na Zona da Mata de Minas Gerais. Dissertação de Mestrado. Universidade Federal de Viçosa, Viçosa. 116p.

Leal-Filho, N. 1972. Contribuição ao conhecimento taxonômico da tribo Vernonieae no estado de São Paulo. Tese de Doutorado. ESALQ, São Paulo. 217p.

Leal-Filho, N. 1991. Compositae (Asteraceae). In: Melo, M.M.R.F.; Barros, F.; Wanderley, M.G.L.; Kirizawa, M.; Jung-Mendaçolli, S.L. \& Chiea, S.A.C. (eds.). Flora fanerogâmica da Ilha do Cardoso: Caracterização geral da vegetação e listagem das espécies ocorrentes. Vol 1. Instituto de Botânica, São Paulo. Pp. 84-88.

Leal-Filho, N. \& Semir, J. 1987. Compositae. In: Giulietti, A.M. et al. Flora da Serra do Cipó, Minas Gerais: Caracterização e lista das espécies. Boletim de Botânica da Universidade de São Paulo 9:29-41.

Lorenzi, H. 1991. Plantas daninhas do Brasil. 2 ed. Plantarum, Nova Odessa. 440p.

Moraes, M.D. 1997. A família Asteraceae na Planície Litorânea de Picinguaba Município de Ubatuba - São Paulo. Dissertação de Mestrado. Universidade Estadual de Campinas, Campinas. 154p.

Moraes, M.D. \& Monteiro, R. 2006. A família Asteraceae na planíce litorânea de Picinguaba, Ubatuba, São Paulo. Hoehnea 33(1): 41-78.

Nakajima, J. N. 2000. A família Asteraceae no Parque Estadual da Serra da Canastra, Minas Gerais, Brasil. Tese de Doutorado. Universidade Estadual de Campinas, Campinas. 467p.

Nakajima, J.N. \& Semir, J. 2001. Asteraceae do Parque Nacional da Serra da Canastra, Minas Gerais, Brasil. Revista Brasileira de Botânica 24: 471-478.

Nakajima, J.N.; Esteves, R.L.; Esteves, V.G.; Magenta, M.A.G; Bianchini, R.S.; Pruski, J.F. \& Hind, D.J.N. 2001. Flora Fanerogâmica da Reserva do Parque Estadual das Fontes do Ipiranga (São Paulo, Brasil). Hoehnea. 28(2): 111-181.

Pruski, J.F. 1997. Asteraceae. In: Berry, P.E.; Holst, B.K. \& Yatskievych, K. Flora of the Venezuelan Guayana. Vol. 3 (Araliaceae-Cactaceae). Missouri Botanical Garden, St. Louis. Pp. 177-393.

Roque, N. \& Pirani, J.R. 1997. Flora da Serra do Cipó, Minas Gerais: Compositae- Barnadesieae e Mutisieae. Boletim de Botânica da Universidade de São Paulo 16: 151-185. 
Souza, F.O. 2007. Asteraceae no Parque Estadual da Ilha do Cardoso, Cananéia, SP. Dissertação de Mestrado. Instituto de Botânica de São Paulo, São Paulo. 159p.
Veloso, H.P. \& Góes-Filho, L. 1982. Fitogeografia brasileira: classificação fisionômica ecológica da vegetaçãoneotropical.In:ProjetoRADAMBRASIL. Boletim Técnico Série Vegetação. Vol 1.85p. 